\title{
ARTIKELEN
}

\section{Rechterlijke toetsing van regelgeving}

\author{
Wat is de betekenis van recente ontwikkelingen in de \\ rechtspraak voor de wetgevingspraktijk van de \\ bestuurswetgever?*
}

G.J.M. Evers \& J.C.A. de Poorter

\section{Inleiding}

Op 22 december 2017 nam staatsraad advocaat-generaal Widdershoven een belangwekkende conclusie over de wijze waarop de bestuursrechters algemeen verbindende voorschriften exceptief moeten toetsen. ${ }^{1}$ De staatsraad advocaatgeneraal was gevraagd in zijn conclusie in te gaan op de vraag hoe intensief de bestuursrechter een algemeen verbindend voorschrift exceptief moet toetsen aan ongeschreven recht en welke omstandigheden daarvoor bepalend zijn. Volgens de staatsraad advocaat-generaal zijn er goede redenen om algemeen verbindende voorschriften indringender (exceptief) te toetsen en de zogenoemde 'willekeurstoetsing' - die sinds het Landbouwvliegers-arrest in 1986 door rechters wordt toegepast - los te laten. Deze conclusie werd pas op 1 juli 2019 gevolgd door een principiële uitspraak van de Centrale Raad van Beroep (CRvB). ${ }^{2}$ Op 12 februari 2020 sloot de Afdeling bestuursrechtspraak (ABRvS) zich bij deze uitspraak van de $\mathrm{CRvB}$ aan. ${ }^{3}$ De hoogste bestuursrechters lijken met deze rechtspraak te bevestigen dat een algemeen verbindend voorschrift zonder meer aan het evenredigheidsbeginsel (en aan andere materiële rechtsbeginselen) kan worden getoetst zonder tussenkomst van de 'willekeursluis'. Dat is in zoverre niet nieuw dat de ABRvS ook al in de uitspraak over het alcoholslot heeft laten zien een algemeen verbindend voorschrift rechtstreeks aan artikel 3:4, tweede lid, van de Algemene wet bestuursrecht (Awb) te toetsen. ${ }^{4}$ Wat wel opvallend is, is dat de bestuursrechters de staatsraad advocaat-generaal niet volgen waar deze concludeerde dat ook bij schending van een formeel beginsel een algemeen verbindend voorschrift onverbindend kan worden verklaard.

De vraag die in deze bijdrage centraal staat, is: welke gevolgen heeft deze rechtspraak voor de wetgevingspraktijk? Daartoe zullen wij allereerst ingaan op de

* De auteurs schreven deze bijdrage op persoonlijke titel. Zij danken staatsraad N. Verheij voor zijn kritische blik bij een eerdere versie van dit artikel.

1 Concl. A-G Widdershoven 22 december 2017, ECLI:NL:RVS:2017:3557.

2 CRvB 1 juli 2019, ECLI:NL:CRVB:2019:2016.

3 ABRvS 12 februari 2020, ECLI:NL:RVS:2020:452.

4 ABRvS 4 maart 2015, ECLI:NL:RVS:2015:622. 
vraag naar de bijzondere aard van de rechterlijke toetsing van regelgeving (par. 2). Vervolgens gaan we in op de betekenis van de hiervoor genoemde uitspraken voor de (toekomstige) exceptieve rechtmatigheidstoetsing van regelgeving door de bestuursrechter (par. 3). Wat de betekenis is van meer of minder indringende toetsing en in welke gevallen meer of minder indringende toetsing wordt toegepast, is hier van bijzonder belang (par. 4). Vervolgens stellen wij ons de vraag wat deze rechtspraak betekent voor de wetgevingspraktijk en werpen wij andersom de vraag op welke rol het wetgevingsbeleid kan spelen in de rechterlijke toetsing van regelgeving, en in het verlengde hiervan of een indringender rechterlijke toetsing niet de behoefte doet ontstaan aan duidelijkere regels over regelgeving (par. 5). In de conclusie zullen wij betogen dat nu de wetgever aan zet is om de eisen aan bestuurswetgeving (beter) te reguleren. Wij ronden af met een aantal voorstellen over hoe die eisen zouden moeten luiden (par. 6).

\section{De bijzondere aard van de rechterlijke toetsing van regelgeving}

Wat betreft de toetsing van wetgeving kennen we in Nederland een cultuur van constitutionele terughoudendheid. Deze terughoudendheid omvat de beperkte bevoegdheid van de rechter om een algemeen verbindend voorschrift te toetsen (denk aan art. 120 Grondwet), de ontbrekende mogelijkheid om directe bestuursrechtelijke rechtsbescherming te vragen tegen een algemeen verbindend voorschrift (denk aan art. 8:3 Awb) en de terughoudende wijze van rechterlijke toetsing van een algemeen verbindend voorschrift aan het ongeschreven recht. Traditioneel wordt daarbij een aantal argumenten genoemd om te rechtvaardigen dat algemeen verbindende voorschriften een andere - meer terughoudende benadering verdienen dan andere publiekrechtelijke rechtshandelingen:

1 de bijzondere status van de wetgever in formele zin en de bijzondere afgeleide status van gedelegeerde wetgevers;

2 de bijzondere waarborgen die bij de vaststelling van algemeen verbindende voorschriften in acht worden genomen;

3 de taak die de rechter in het staatsbestel (niet) heeft; en

4 de bijzondere aard van algemeen verbindende voorschriften.

Wij willen hier vooral ingaan op de bijzondere aard van algemeen verbindende voorschriften en - in dat licht - de taak die (mogelijk) een rechter (niet) heeft. In het Nederlands staatsbestel nemen de wetgever en het bestuur besluiten om maatschappelijke belangen te behartigen. Zij doen dat op basis van hun bevoegdheden om publiekrechtelijke rechtshandelingen vast te stellen. De rechter heeft vervolgens de taak om rechtsbescherming te bieden. Hij beoordeelt - voor zover hij daartoe de bevoegdheid heeft - de rechtmatigheid van de publiekrechtelijke rechtshandelingen die door de wetgever en het bestuur zijn vastgesteld. Deze beoordeling gaat niet zover dat de rechter de afweging van het bestuur overdoet. De rechter maakt zelf geen inhoudelijke afweging, maar beoordeelt of de afweging van de wetgever of het bestuur in overeenstemming is met de rechtsregels waaraan de wetgever of het bestuur is gebonden. 
Algemeen verbindende voorschriften hebben een ander karakter dan andere publiekrechtelijke rechtshandelingen. Ten eerste moeten algemeen verbindende voorschriften zijn vastgesteld op basis van een regelgevende bevoegdheid die te herleiden moet zijn tot de Grondwet of de wet in formele zin. Ten tweede zijn algemeen verbindende voorschriften algemeen toepasbaar. Dit betekent dat de voorschriften toepasbaar zijn op een open groep van geadresseerden. De algemene strekking betreft bovendien de mogelijkheid tot herhaalde toepassing van het voorschrift. ${ }^{5}$ De vraag is daarmee of het algemeen verbindende karakter van wettelijke regels, voor zover de rechter tot toetsing bevoegd is, een andere wijze van toetsing met zich brengt dan de toetsing van andere publiekrechtelijke rechtshandelingen.

Volgens Van Male moet bestuurswetgeving worden beschouwd als een bestuursdaad en dient zij overeenkomstig te worden behandeld. ${ }^{6}$ Of zoals Polak en Van Buuren betoogden, het is een kwestie van wetgevingstechniek of een bepaalde norm wordt opgelegd door een algemeen verbindend voorschrift of een beschikking. ${ }^{7}$ Daartegenover kan men echter wijzen op het ordenende karakter van wetgeving; een wettelijke regel heeft de functie om in verschillende gevallen en op verschillende tijdstippen te worden toegepast. De regel geeft daarmee invulling aan het gelijkheidsbeginsel en rechtszekerheidsbeginsel. Daarbij is het de vraag of bij een beoordeling van een algemeen verbindend voorschrift de rechter oog zou moeten hebben voor het feit dat dit voorschrift is vastgesteld voor toepassing in een open groep van gevallen en op verschillende tijdstippen. Als de bestuurswetgever immers de rechtmatigheid van het voorschrift niet op één individueel en concreet geval heeft kunnen beoordelen, moet de rechter dan in zijn beoordeling van de rechtmatigheid van het algemeen verbindend voorschrift uitsluitend oog hebben voor de rechtsgevolgen in een bepaalde situatie op een bepaald rechtssubject, of zou hij er rekening mee moeten houden dat de bestuurswetgever een abstracte beoordeling van de rechtmatigheid heeft moeten uitvoeren? In het kader van een toetsing van het algemeen verbindend voorschrift aan eenduidige hogere regels is het antwoord op deze vraag negatief; het is immers helder waar het voorschrift de grens van het hogere recht overschrijdt. Dat is mogelijk minder evident als de rechtmatigheid van het algemeen verbindend voorschrift niet onmiddellijk uit het hogere recht is af te leiden. Zijn in dat geval de rechtszekerheid en rechtsgelijkheid gediend, indien de rechter de rechtmatigheid van het algemeen verbindend voorschrift bij iedere concrete toepassing opnieuw - en mogelijk anders - beoordeelt?

Een ander kenmerk van algemeen verbindende voorschriften is dat zij doorgaans worden vastgesteld op grond van een relatief open bevoegdheid. Sommige bevoegdheden tot vaststelling van algemeen verbindende voorschriften zijn bijna

5 Zie bijv. W. Konijnenbelt \& R. van Male, Hoofdstukken van bestuursrecht, Deventer: Kluwer 2014, hoofdstuk 6, par. 7.

6 R.M. van Male, Rechter en bestuurswetgeving, Zwolle: W.E.J. Tjeenk Willink 1988, p. 496.

$7 \quad$ P.J.J. van Buuren, 'Onrechtmatige wetgeving', in: De rechter en onrechtmatige wetgeving. Preadviezen Nederlandse Juristen-Vereniging, deel I, Zwolle: W.E.J. Tjeenk Willink 1987, p. 3-99; J.E.M. Polak, 'Onrechtmatige wetgeving', in: De rechter en onrechtmatige wetgeving. Preadviezen Nederlandse Juristen-Vereniging, deel I, Zwolle: W.E.J. Tjeenk Willink 1987, p. 103-194. 
onbegrensd. De wetgever in formele zin, provinciale staten en de gemeenteraad hebben een autonome bevoegdheid tot het vaststellen van regels. Deze wordt slechts begrensd door het grondgebied waarop de bevoegdheid geldend is, de competentie van andere bestuurslagen, algemene rechtsbeginselen, algemeen verbindende voorschriften van hogere orde en bijvoorbeeld grondrechten. Ook gedelegeerde bevoegdheden tot regelgeving kunnen een zeer ruime bevoegdheid betreffen. Normaliter zal bij delegatie van regelgevende bevoegdheid het onderwerp of het belang van de gestelde regels een gegeven zijn. Niettemin zal ook dan in veel gevallen de aard van de bevoegdheid relatief open zijn en het aantal keuzemogelijkheden relatief groot. Op grond van het positieve recht is daar ook niets op tegen. Het primaat van de wetgever, dat een onderscheid aanbrengt in de onderwerpen die op hoger respectievelijk lager regelstellend niveau mogen worden geregeld, vormt - buiten de grondwettelijke beperkingssystematiek vooral een beleidsmatig uitgangspunt.

Die grote beslissingsruimte maakt algemeen verbindende voorschriften niet immuun voor rechterlijke toetsing, maar heeft van oudsher wel invloed gehad op de rechterlijke toetsingsintensiteit. Zoals Duk het formuleerde:

'De afweging van belangen in abstracto, bij elke beleidsvorming vereist, is niet geheel onvatbaar voor naweging op de schaal van Themis. Het gewicht dat aan de in aanmerking te nemen belangen moet worden toegekend, hangt weliswaar goeddeels van politieke opties en prioriteiten af - en onttrekt zich, voor zover het daarvan afhangt, aan correctie door wie geen politieke verantwoordelijkheid draagt - voor het resultaat van de afweging mag als minimum-eis van recht gelden, dat een bestuurder, gegeven zijn politieke doelstellingen en uitgangspunten in redelijkheid en eerlijkheid tot dit resultaat heeft kunnen komen.8

Die relatief grote afwegingsruimte die het bestuur veelal heeft bij het tot stand brengen van bestuurswetgeving creëert derhalve geen rechtsvrije ruimte: politieke besluitvorming, hoe discretionair van aard ook, is gebonden aan de plicht tot belangenafweging als een minimumeis van recht. Vindt er geen belangenafweging plaats, dan is de beslissing irrationeel en daarmee kennelijk onredelijk. Zoals Van Male schreef, ${ }^{9}$ wordt daarmee duidelijk dat er een nauw verband is tussen het aan de klassieke wetsidee ten grondslag liggende rationaliteitsbeginsel en het verbod van willekeur zoals dat door de Hoge Raad in het Landbouwvliegers-arrest als toetsingsstandaard voor algemeen verbindende voorschriften is voorgeschreven. ${ }^{10}$

De rechterlijke toetsingsintensiteit kan worden verklaard uit de wijze waarop wij de verhouding tussen rechter, bestuur en wetgever gewend zijn te beoordelen. De idee dat de ruimte die aan de bestuurswetgever is gelaten een politieke speelruimte is waarbinnen het bestuur onder politieke aansturing belangen afweegt en

8 W. Duk, 'De zachte kern van het bestuursrecht', RMThemis 1978, p. 576.

$9 \quad$ Van Male 1988, p. 348.

10 HR 16 mei 1986, ECLI:NL:HR:1986:AC9354, AB 1986/574, m.nt. P.J.J. van Buuren. 
zich daarvoor politiek moet verantwoorden ten overstaan van vertegenwoordigende lichamen, werkt nog steeds door in de legitimatie van rechterlijke 'terughoudendheid' in de toetsing van regelgeving. Het gevolg van deze constitutionele redenering is - zoals Hirsch Ballin het formuleert - dat de discretionaire ruimte voor het bestuur, voor de rechterlijke taak een relatief vacuüm is. ${ }^{11}$ Mede vanuit een oogpunt van individuele rechtsbescherming is zo'n juridisch vacuüm niet wenselijk. Onder andere om die reden is er de afgelopen jaren een discussie ontstaan over de indringendheid van de rechterlijke toetsing van bestuurswetgeving.

\section{Wat is de betekenis van de recente rechtspraak van $C R v B$ en $A B R v S$ voor (toekomstige) toetsing van algemeen verbindende voorschriften door de rechter?}

Wat leren de uitspraken van de CRvB van 1 juli 2019 en de ABRvS van 12 februari 2020 ons nu precies over de wijze waarop algemeen verbindende voorschriften door de bestuursrechters dienen te worden getoetst? Bij nadere analyse van deze uitspraken valt ten minste een drietal dingen op.

\subsection{Exit willekeursluis}

De beide hoogste bestuursrechters maken duidelijk dat algemeen verbindende voorschriften voortaan kunnen worden getoetst aan materiële rechtsbeginselen zonder toepassing van de willekeursluis. Daarmee wordt definitief afstand genomen van de Landbouwvliegers-toetsingsstandaard. Een schending van materiële beginselen zal ertoe kunnen leiden dat het algemeen verbindend voorschrift onverbindend wordt verklaard.

\subsection{Beperkte betekenis van formele rechtsbeginselen}

Wat verder opvalt is dat algemeen verbindende voorschriften weliswaar aan formele beginselen van behoorlijk bestuur kunnen worden getoetst, maar dat schending van het formele zorgvuldigheidsbeginsel of van het motiveringsbeginsel op zichzelf niet tot het onverbindend verklaren van het algemeen verbindend voorschrift kan leiden. De bestuursrechters overwegen:

'De enkele strijd met deze formele beginselen kan echter niet leiden tot het onverbindend achten van een algemeen verbindend voorschrift. Dat laat onverlet dat, indien als gevolg van een gebrekkige motivering of onzorgvuldige voorbereiding van het voorschrift door de rechter, niet kan worden beoordeeld of er strijd is met hogere regelgeving, de algemene rechtsbeginselen of de algemene beginselen van behoorlijk bestuur, dit ertoe kan leiden dat de bestuursrechter het voorschrift buiten toepassing laat en een daarop berustend besluit om die reden vernietigt.'

11 E.M.H. Hirsch Ballin, 'Dynamiek in de bestuursrechtspraak', in: Rechtsontwikkeling door de bestuursrechter (VAR-reeks 154), Den Haag: Boom Juridische uitgevers 2015, p. 26-27. 
Een eerste vraag die onmiddellijk opkomt, is wat nu precies de betekenis is van de overweging die $\mathrm{CRvB}$ en $\mathrm{ABRvS}$ hier met betrekking tot de formele algemene beginselen van behoorlijk bestuur hanteren. De hoogste bestuursrechters maken duidelijk dat de formele rechtsbeginselen een rol spelen bij de toetsing van algemeen verbindende voorschriften, maar enkel in relatie tot een toetsing aan hogere regelgeving, de algemene rechtsbeginselen of de algemene beginselen van behoorlijk bestuur. Deze benadering vertoont een zekere gelijkenis met de willekeursluis, die door de uitspraak bij de materiële algemene beginselen van behoorlijk bestuur juist wordt verlaten. Waar eerst het verbod van willekeur de centrale toetssteen of 'sluis' was, waarlangs de toetsing aan het ongeschreven recht plaatsvond, wordt deze toetssteen - wat betreft het motiveringsbeginsel en het formele zorgvuldigheidsbeginsel - nu gevormd door een mogelijke schending van hogere regelgeving, de algemene (materiële?) rechtsbeginselen of de (materiële?) algemene beginselen van behoorlijk bestuur. De 'nieuwe' sluis, die uitsluitend geldt voor formele beginselen, is of door gebreken in bijvoorbeeld de voorbereiding en motivering van het besluit de materiële rechtmatigheid van het algemeen verbindend voorschrift nog wel kan worden beoordeeld. Kan die materiële beoordeling niet plaatsvinden, dan kan de rechter het algemeen verbindend voorschrift buiten toepassing laten.

Vervolgens is de vraag waarom de $C R v B$ en de $A B R v S$ tot het oordeel komen dat een algemeen verbindend voorschrift niet enkel op een schending van formele beginselen onverbindend kan worden geacht of buiten toepassing worden gelaten. Misschien is die reden gelegen in de omstandigheid dat formele gebreken naar hun aard herstelbaar zijn, zonder dat daarmee noodzakelijkerwijs de inhoud van het besluit wijzigt. Aan de andere kant lijkt ons een gebrekkig onderzoek bij de totstandkoming van regelgeving, zoals het niet in kaart brengen van de gevolgen of het niet consulteren van belanghebbenden, op zichzelf wel een zodanig ernstig gebrek dat de vraag is of dit voorschrift in stand kan blijven. Kan immers een algemeen verbindend voorschrift dat tot stand is gekomen zonder dat voldoende relevante feiten en belangen zijn verzameld, überhaupt het resultaat zijn van een adequate materiële afweging van die feiten en belangen? De vraag is bovendien waarom de schending van het formele beginsel, die leidt tot de vaststelling dat de materiële rechtmatigheid niet kan worden vastgesteld, kennelijk slechts kan leiden tot het buiten toepassing laten van het voorschrift en niet tot onverbindendheid. Waarom zou een voorschrift dat niet adequaat is voorbereid of onvoldoende is gemotiveerd, in andere gevallen dan de bij de rechter voorliggende casuspositie eigenlijk wél mogen worden toegepast? Zal de rechter dan nooit kunnen vaststellen dat het formele gebrek zo fundamenteel is, dat de materiële afweging in geen geval kan worden geacht te hebben plaatsgehad? Omgekeerd rijst de vraag of de bestuursrechter daarmee ook heeft willen zeggen dat een gebrek in de materiële afweging van het besluit wel altijd zou moeten leiden tot onverbindendheid van het voorschrift. Die consequentie is niet vanzelfsprekend, omdat denkbaar is dat de toepassing van een voorschrift in het ene geval onevenredig moet worden geoordeeld, en in het andere geval prima door de beugel kan. De aard van het (primair) geschonden beginsel is met andere woorden niet zo'n sterk criterium om de gevolgen van de schending vast te stellen. Deze 
gevolgen zouden naar onze mening moeten worden bepaald in het licht van de aard van de schending, zoals de ernst daarvan en wie daardoor worden geraakt.

Ten slotte is het de vraag welke verwachtingen we van deze nieuwe procedurele toetsing mogen koesteren, gelet op hetgeen de CRvB en de ABRvS daarover overwegen:

'Als het vaststellende orgaan bij het voorbereiden en nemen van een algemeen verbindend voorschrift de negatieve gevolgen daarvan voor een bepaalde groep uitdrukkelijk heeft betrokken en de afweging deugdelijk heeft gemotiveerd, voldoet deze keuze aan het zorgvuldigheids- en het motiveringsbeginsel en beperkt de toetsing door de bestuursrechter zich in het algemeen tot de vraag of de regeling in strijd is met het evenredigheidsbeginsel.'

Deze toetsing aan formele zorgvuldigheid en motivering lijkt enerzijds niet verder te gaan dan de vraag óf de negatieve gevolgen voor een bepaalde groep in de besluitvorming zijn betrokken. Over de wijze waarop dat ex-anteonderzoek is verricht, lijken de bestuursrechters zich niet te willen uitspreken. Anderzijds is het de vraag of de motivering van de afweging die het bestuursorgaan heeft gemaakt wel deugdelijk kán zijn, als de (positieve) effecten van het voorschrift op het maatschappelijk belang en de (negatieve) effecten voor een bepaalde groep niet voldoende adequaat in kaart zijn gebracht. Vormt met andere woorden de wijze waarop het voorbereidende onderzoek is verricht niet een sine qua non voor een deugdelijke motivering van het algemeen verbindend voorschrift, zonder welke de materiële rechtmatigheid van het besluit niet kan worden vastgesteld?

\subsection{Factoren die de intensiteit van de toetsing bepalen}

De $C R v B$ en de ABRvS overwegen dat de intensiteit van de toetsing afhankelijk is van onder meer de beslissingsruimte die het vaststellend orgaan heeft, gelet op de aard en inhoud van de vaststellingsbevoegdheid en de daarbij te betrekken belangen. Die beoordeling kan materieel terughoudend zijn als de beslissingsruimte voortvloeit uit de feitelijke of technische complexiteit van de materie, dan wel als bij het nemen van de beslissing politiek-bestuurlijke afwegingen kunnen worden of zijn gemaakt. In dat laatste geval, zo overwegen beide colleges, heeft de rechter niet de taak om de waarde of het maatschappelijk gewicht dat aan de betrokken belangen wordt toegekend naar eigen inzicht vast te stellen. Wat betreft de in acht te nemen belangen en de weging van die belangen geldt dat de beoordeling daarvan intensiever kan zijn naarmate het algemeen verbindend voorschrift meer ingrijpt in het leven van de belanghebbende(n) en daarbij fundamentele rechten aan de orde zijn.

Wat de $C R v B$ en de $A B R v S$ precies bedoelen met een materieel terughoudende toetsing of met een 'intensievere' beoordeling wordt in de beide uitspraken niet nader toegelicht. Mogelijk hebben de CRvB en de ABRvS met een materieel terughoudende toetsing vooral het oog op die elementen of aspecten die betrekking hebben op de inhoud van de besluitvorming en niet op de procedure van totstandkoming ervan. Dit zou de verwachtingen omtrent deze toetsing uit het oog- 
punt van de individuele rechtsbescherming mogen temperen. Toetsing aan de formele beginselen kan gelet op de uitspraak immers - hoe intensief ook - op zichzelf al niet tot onverbindendheid leiden. Als dit vervolgens gepaard gaat met een terughoudende toetsing van de materiële aspecten, laat dat ons inziens weinig van de toetsing over.

Daarmee is een heel basale vraag echter nog onbeantwoord gebleven, namelijk: wat bedoelen de $C R v B$ en de $A B R v S$ nu precies als ze spreken over een terughoudende of intensievere rechterlijke toetsing? De intensiteit van de toetsing is blijkbaar afhankelijk van verschillende factoren, maar wat zijn dan de daarbij behorende toetsingsmodaliteiten die $\mathrm{CRvB}$ en $\mathrm{ABRvS}$ op het oog hebben? Daarover zwijgen zij in hun uitspraken.

\section{Wat moet worden verstaan onder een meer of minder indringende toetsing?}

\subsection{Terughoudende toetsing als een methode van rechterlijke toetsing}

In het jaarverslag van 2017 geeft de ABRvS aan dat zij is afgestapt van het gebruik van de term 'marginale toetsing', omdat deze een te vrijblijvende opstelling van de rechter suggereert. ${ }^{12}$ Voortaan spreekt zij van een meer of minder indringende toetsing.

Van oudsher is betoogd dat, indien de democratisch gelegitimeerde wetgever bewust beoordelings- en/of beleidsvrijheid toekent aan het bestuursorgaan, de rechter het bestreden besluit in dat geval marginaal (of: terughoudend) moet toetsen. Die terughoudendheid manifesteert zich doordat de rechter slechts bewaakt of het bestuur met de uitoefening van die bevoegdheid is gebleven binnen de grenzen van het recht, al zijn er andere en wellicht in de ogen van de rechter 'betere' besluiten mogelijk. We zijn door de jaren heen gewend geraakt om over de terughoudende toetsing door de rechter te denken in ruimtelijke metaforen: de rechter laat een zekere ruimte of zelfs vrijheid aan het bestuur. Die laatste term is naar het oordeel van de ABRvS verwarrend, omdat geen enkel gebruik van een publiekrechtelijke bevoegdheid geheel vrij is, maar steeds gebonden aan regels van het recht. ${ }^{13}$ Daarom heeft de ABRvS inmiddels de termen 'beleidsvrijheid' en 'beoordelingsvrijheid' in haar uitspraken vervangen door 'beleidsruimte' en 'beoordelingsruimte', met als overkoepelende term 'beslissingsruimte'.

Kenmerkend aan de meer of minder indringende (voorheen: marginale) toetsing is dat de rechter niet zijn eigen waardering geeft van wat 'redelijk' of wat 'onredelijk' is. In Maxis/Praxis heeft de ABRvS het heel duidelijk gezegd: '(...) het is niet de bedoeling dat de rechter gaat beoordelen welke nadelige gevolgen nog wel en welke niet meer evenredig zijn, of dat de rechter gaat uitmaken welke uitkomst van de belangenafweging als het meest evenwichtig moet worden beschouwd.' ${ }^{14}$ De rechter dient zich naar het oordeel van de ABRvS te beperken tot de vraag 'of 
sprake is van een zodanige onevenwichtigheid van de afweging van de betrokken belangen, dat moet worden geoordeeld dat het bestuur niet in redelijkheid tot het nemen van het bestreden besluit heeft kunnen komen'. Daarmee verschilt de meer of minder indringende toetsing van de belangenafweging van andere vormen van toetsing. In de meeste gevallen is de rechterlijke controle gericht op de vraag of er een wettelijk voorschrift is geschonden. Dat is een type vraag, hoe moeilijk ook, dat met ja of nee kan worden beantwoord. Dat is anders bij een meer of minder indringende toetsing. Het gaat hier om een toetsing aan beginselen. Die kan niet digitaal zijn in de zin dat de rechter zelf de lijn trekt waar redelijkheid stopt en onredelijkheid begint. De rechter vernietigt slechts wanneer de uitkomst van de belangenafweging evident onredelijk is, daarmee niet alleen besluiten in stand latend die evident redelijk zijn, maar ook besluiten die dat naar zijn mening wellicht niet zijn, maar waarvan de evidente onredelijkheid niet is komen vast te staan.

Deze meer of minder indringende toetsing is een methode van toetsing aan beginselen. Op zichzelf zegt die echter nog niets over de mate van indringendheid waarmee die toetsing wordt uitgevoerd. Waar een bestuursorgaan beschikt over een zekere beslissingsruimte, ziet de rechter zich geplaatst voor de vraag hoe indringend hij de uitoefening van die bevoegdheid dient te toetsen.

\subsection{Meer of minder indringende toetsing van het evenredigheidsbeginsel}

Wat wordt nu precies bedoeld als we zeggen dat de rechter soms terughoudend(er) en soms indringend(er) moet toetsen? Dit kunnen we goed laten zien aan de hand van de wijze van toetsing aan het evenredigheidsbeginsel. In de toetsing van bestuurlijke beslissingsruimte speelt het evenredigheidsbeginsel een belangrijke rol. Dit beginsel stelt grenzen aan de beslissingsruimte voor het bestuur door van het bestuur een evenwichtige belangenafweging te eisen, en het beoogt burgers te beschermen tegen bestuurlijke willekeur. Als het gaat om de toetsing aan het materiële beginsel van evenredigheid is een duidelijke ontwikkeling waarneembaar in de tijd.

\section{- Naar meer indringende toetsing op evenredigheid}

In het Landbouwvliegers-arrest sprak de Hoge Raad uit dat voortaan algemeen verbindende voorschriften zouden moeten worden getoetst aan ongeschreven recht, maar dan wel terughoudend, dat wil zeggen uitsluitend aan het verbod van willekeur. De rechter mocht slechts ingrijpen wanneer een maatregel was genomen waartoe in redelijkheid niet gekomen had kunnen worden, waarbij een rol zou kunnen spelen of er sprake was van schending van meer formele beginselen als motivering en zorgvuldigheid. ${ }^{15}$ Het ging hier dus om een indirecte toetsing aan algemene beginselen van behoorlijk bestuur via het materiële beginsel van het verbod van willekeur. Die willekeurstoetsing is een voorbeeld van een heel terughoudende wijze van toetsing van het overheidsoptreden, bedoeld voor 
exceptionele gevallen waarin een besluit is genomen dat geen redelijk denkend mens voor zijn of haar rekening kan nemen.

Bij de totstandkoming van de Awb werd in artikel 3:4, tweede lid, het evenredigheidsbeginsel gecodificeerd. De vraag was of daarmee de toetsing minder terughoudend zou zijn. De ABRvS maakte echter in Maxis/Praxis duidelijk dat de wetgever met dit tot het bestuur gerichte voorschrift niet had beoogd de rechterlijke toetsing te intensiveren ten opzichte van de rechtspraak zoals die zich tot dat moment had ontwikkeld. Volgens de memorie van antwoord is het niet de bedoeling dat de rechter gaat beoordelen welke nadelige gevolgen nog wel en welke niet meer evenredig zijn, of dat de rechter gaat uitmaken welke uitkomst van de belangenafweging als het meest evenwichtig moet worden beschouwd. ${ }^{16}$ Dit standpunt van de wetgever was naar het oordeel van de ABRvS gebaseerd op de onderscheiden posities die de onafhankelijke rechter en het politiek verantwoordelijke bestuur in het staatsbestel innemen. Uit de memorie van antwoord blijkt ook dat met de formulering van artikel 3:4, tweede lid, Awb - met toepassing van een dubbele ontkenning ('niet onevenredig') - is beoogd de rechter te nopen tot terughoudendheid bij de toetsing van de belangenafweging door het bestuur.

Een nieuwe stap in de ontwikkeling lijkt zich echter te hebben voorgedaan met de uitspraak in de zaak over het alcoholslotprogramma. De ABRvS komt in die zaak tot het oordeel dat in de Regeling maatregelen rijvaardigheid en geschiktheid 2011 de evenredigheid van de opgelegde maatregel onvoldoende gewaarborgd is, zodat artikel 17, eerste lid, van de Regeling in strijd is met artikel 3:4, tweede lid, van de Awb en derhalve onverbindend is. Anders dan voorheen toetst de ABRvS hier een algemeen verbindend voorschrift wel rechtstreeks aan artikel 3:4, tweede lid, Awb. ${ }^{17}$ Daarmee breekt de ABRvS met de jurisprudentielijn uit Maxis/Praxis, waarin het evenredigheidsbeginsel uit artikel 3:4, tweede lid, Awb nog werd gezien als een tot het bestuursorgaan gericht voorschrift, maar niet als een rechterlijke toetsingsnorm. Voorts blijkt uit deze uitspraak dat een rechtstreekse toetsing van algemeen verbindende voorschriften aan het evenredigheidsbeginsel mogelijk is zonder willekeursluis.

- Naar een toetsing op verschillende materiële aspecten binnen evenredigheid

De toetsing aan het evenredigheidsbeginsel in de zaak over het alcoholslot is een toetsing op de evenredigheid van de maatregel in strikte zin (stricto sensu). De jurisprudentie van het Hof van Justitie van de Europese Unie (HvJ EU) laat echter zien dat de toetsing aan het evenredigheidsbeginsel zich over meer aspecten kan uitstrekken dan uitsluitend op evenredigheid stricto sensu. Bij de beoordeling van besluiten in het licht van het evenredigheidsbeginsel hanteert het HvJ EU een doel-middeltoetsing, waarin drie stappen kunnen worden onderscheiden:

a Is het besluit daadwerkelijk geschikt om het doel te bereiken?

b Is het besluit noodzakelijk, in die zin dat minder ingrijpende alternatieven niet tot dat doel leiden? 
c Een beoordeling van de evenredigheid stricto sensu of de evenwichtigheid van de maatregel, waarbij wordt beoordeeld of een op zichzelf geschikte en noodzakelijke maatregel niet onredelijk bezwarend is voor de betrokken burgers.

De toetsing die het HvJ EU verricht in het kader van de evenredigheidsbeoordeling is daarmee in de breedte intensiever dan een toetsing op evenredigheid stricto sensu; de toets vindt op meerdere onderdelen plaats. Tegelijkertijd is zij daarmee niet noodzakelijkerwijs diepgaander: het HvJ EU toetst EU-wetgeving bijvoorbeeld slechts op 'kennelijke ongeschiktheid', wat geen diepgaande toetsing behelst. In zijn conclusie van 22 december 2017 bepleit staatsraad advocaat-generaal Widdershoven dat de hoogste bestuursrechters zich in Nederland bij die drietrapsproportionaliteitstoets van het HvJ EU aansluiten. ${ }^{18}$ Ook in de literatuur zijn pleidooien in die richting te vinden. ${ }^{19}$ In de uitspraken van de $C R v B$ van 1 juli 2019 en de ABRvS van 17 februari 2020 hebben de hoogste rechters die lijn echter niet, of althans nog niet expliciet omarmd.

\section{- De betekenis van formele beginselen binnen het kader van de evenredigheidstoetsing}

De rechtspraak laat enkele voorbeelden zien van toetsing van algemeen verbindende voorschriften aan het zorgvuldigheidsbeginsel en het motiveringsbeginsel. Wat opvalt is dat deze toetsing aan zorgvuldigheid en motivering heel vaak het spoor volgt van het vereiste van evenredigheid stricto sensu, waarbij wordt beoordeeld of de belangen van de groep betrokken burgers voor wie de gewraakte maatregel potentieel onredelijk bezwarend is, in de belangenafweging zijn betrokken, en of de beslissing op dat punt deugdelijk is gemotiveerd. ${ }^{20}$

Ook de elementen van geschiktheid en noodzakelijkheid zouden kunnen worden betrokken in de betekenis die formele beginselen van behoorlijk bestuur spelen in de toetsing van algemeen verbindende voorschriften. De vraag naar de geschiktheid van de maatregel lijkt als zodanig in de toetsing door de bestuursrechters geen rol te spelen, maar als een maatregel evident niet kan bijdragen aan het doel waarvoor die maatregel wordt genomen, zal deze waarschijnlijk niet overeind blijven. Hoewel de rechter niet gemakkelijk zal kunnen vaststellen of met de in

19 O.a. Hirsch Ballin 2015, J.C.A. de Poorter \& F. Çapkurt, 'Rechterlijke toetsing van algemeen verbindende voorschriften', NTB 2017/10, T. Barkhuysen, 'De opmars van evenredigheid in het bestuursrecht', NJB 2018/445, A. van Gijssel \& J.P. Heinrich, 'Toetsing van regelgeving aan rechtsbeginselen: een logische nieuwe stap in de queeste naar balans in de Trias', JBplus 2018, afl. 1, p. 13-25 en L.A. van Heusden, 'Exceptieve toetsing 2.0', JBplus 2019, afl. 2, p. 3-20.

20 Zie bijv. CRvB 6 februari 2008, ECLI:NL:CRVB:2008:BC4713 over een wijziging van de Regeling medisch-specialistische zorg Ziekenfondswet, als gevolg waarvan de vervanging van een borstprothese werd uitgesloten van het pakket van verstrekkingen ingevolge de Ziekenfondswet. Hierdoor werden in het bijzonder personen getroffen bij wie destijds op grond van een toen aanvaarde medische indicatie (verminking, lichamelijke functiestoornissen of psychisch lijden) ten laste van de ziekenfondsverzekering een of meer borstprotheses zijn ingebracht. Zie ook CRvB 16 september 2017 (ECLI:NL:CRVB:2017:1476) over een wijziging van het Dagloonbesluit $(\mathrm{AMvB})$, die ingrijpende financiële gevolgen had voor een groep werknemers die niet het hele refertejaar hadden gewerkt. Vergelijkbaar over een andere bepaling uit het Dagloonbesluit is CRvB 19 juli 2017, ECLI:NL:CRVB:2017:2406. 
geding zijnde maatregel daadwerkelijk het beoogde doel kan worden bereikt, kan de rechter hier wel terugvallen op het beginsel dat besluiten zorgvuldig dienen te worden voorbereid. Indien er gerede twijfel bestaat over de geschiktheid van de maatregel, zal kunnen worden geconcludeerd dat het onderzoek naar die geschiktheid niet met de vereiste zorgvuldigheid heeft plaatsgevonden of (eventueel in combinatie met het zorgvuldigheidsbeginsel) dat op het punt van de geschiktheid van de maatregel de motivering niet draagkrachtig is. Hetzelfde geldt voor de noodzakelijkheid van de maatregel. Als een keuze mogelijk is tussen meer geschikte maatregelen, moet die maatregel worden gekozen die de minste belasting voor de getroffen particulieren met zich brengt. Hoewel de Nederlandse bestuursrechters niet expliciet toetsen op de noodzakelijkheid van de maatregel, kan dat vereiste wel kleuring geven aan - en daarmee de intensiteit bepalen van de op het bestuursorgaan rustende plicht om bij de voorbereiding van een besluit de nodige kennis te vergaren omtrent de relevante feiten en de af te wegen belangen (art. 3:2 Awb).

In CRvB 1 juli 2019 en in ABRvS 12 februari 2020 wordt overwogen dat aan het zorgvuldigheids- en het motiveringsbeginsel wordt voldaan als het vaststellend orgaan bij het voorbereiden en nemen van een algemeen verbindend voorschrift de negatieve gevolgen daarvan voor een bepaalde groep uitdrukkelijk heeft betrokken en de afweging deugdelijk heeft gemotiveerd. Die toetsing op zorgvuldigheid en motivering kan een uitwendig onderzoek impliceren, waarbij slechts wordt bezien of er onderzoek is verricht. Zodra dat het geval is, heeft het bestuur aan zijn zorgvuldigheidsplicht voldaan. Die toetsing kan ook verder gaan door te bezien op welke aspecten die toetsing is verricht en of dat een wijze is die aanleiding geeft te veronderstellen dat de uitkomst van dat onderzoek juist en betrouwbaar is.

Dat laatste lijkt te gebeuren in de rechtspraak van het HvJ EU. De formele toetsing die het HvJ EU uitvoert, beperkt zich niet tot de vraag óf er onderzoek is verricht, maar strekt zich ook uit tot de vraag op welke aspecten dat onderzoek is uitgevoerd. ${ }^{21}$ Tegelijkertijd geldt ook dan nog steeds dat aan de kwaliteit van dat onderzoek geen eisen worden gesteld. Daarmee bestaat het risico dat als de data die in het onderzoek zijn betrokken onjuist of niet representatief zijn, de rechterlijke uitspraak in dat gebrek deelt. ${ }^{22}$ Denkbaar is daarom een procedurele toetsingsvariant waarbij sterker wordt 'doorgekeken' naar de inhoud van het onderzoek, zonder dat onderzoek in de rechterlijke procedure over te doen. Dat laatste zou te ver voeren en kan van de rechter niet worden verlangd. Hij is - behalve op het terrein van het recht - immers geen inhoudsdeskundige. Dat neemt niet weg dat hij aan de wijze waarop het onderzoek door het bestuur is verricht wel eisen kan stellen. ${ }^{23}$ Te denken valt aan eisen die te maken hebben met het inschakelen

21 Zie HvJ EU 8 juni 2010, C-58/08, ECLI:EU:C:2010:321 (Vodafone), r.o. 55.

22 Zie R.A.J. van Gestel \& J.C.A. de Poorter, 'Putting Evidence-Based Lawmaking to the Test', The Theory and Practice of Legislation (4) 2016, afl. 2, p. 155-185.

23 N. Verheij heeft dit ooit treffend verwoord: 'Sinds ik bestuursrechter ben, beslis ik vooral over dingen waar ik geen verstand van heb.' Zie N. Verheij, 'Van grensrechter naar geschilbeslechter. Een evolutie in de Nederlandse bestuursrechtspraak', in: Preadviezen Vereniging voor de vergelijkende studie van het recht, Den Haag: Boom juridische uitgevers 2013, p. 67-109. 
van deskundigen die voldoende onafhankelijk en onpartijdig zijn, of aan voorwaarden die kunnen worden gesteld aan de methoden van onderzoek die zijn gebruikt. Op deze wijze kan in elk geval worden voorkomen dat bestuursorganen aan 'cherry picking' doen en hun aannames omtrent de geschiktheid, de noodzakelijkheid en de evenwichtigheid van de maatregel baseren op wat Breyer noemt 'junk science'. ${ }^{24}$

\subsection{Toekomstige toetsingsmodellen binnen het spectrum van materiële en procedurele toetsing}

Een meer of minder indringende toetsing wordt wel geassocieerd met het onderscheid tussen een materiële en een procedurele toetsing. Een terughoudende toetsing wordt dan opgevat als een toetsing niet van de uitkomst van de belangenafweging, maar van de wijze van totstandkoming. Dit onderscheid ligt ten grondslag aan een lange discussie die in de literatuur is gevoerd over de vraag welke algemene beginselen van behoorlijk bestuur zich vooral lenen voor toetsing van algemeen verbindende voorschriften. Er zijn bijvoorbeeld auteurs die een procedurele toetsing voorstaan, omdat aldus wordt voorkomen dat de rechter het gevaar loopt te treden in de innerlijke waarde, billijkheid en opportuniteit van het voorschrift (zie art. 11 Wet algemene bepalingen). ${ }^{25}$

Procedurele toetsing is een techniek die vaak wordt toegepast ter compensatie van een materieel terughoudende evenredigheidstoetsing. Uit de rechtspraak van het HvJ EU weten we bijvoorbeeld dat de rechterlijke toetsing door het Hof van EU-wetgeving aan het evenredigheidsbeginsel materieel terughoudend is, maar dat het Hof ter compensatie kiest voor een tamelijk strikte procedurele toetsing aan dat beginsel. Of, zoals Lenaerts schrijft: '(...) judicial deference in relation to "substantive outcomes" has been counterbalanced by a strict "process review".26 Het onderscheid tussen materiële en procedurele toetsing refereert aan een methode van rechterlijke toetsing. Het probleem met dit onderscheid tussen materiële en procedurele toetsing is echter dat dit op zichzelf niet zoveel lijkt te zeggen over de indringendheid van de toetsing. Er bestaat, zoals Jurgens terecht signaleert, bij velen ten onrechte het idee dat het bij 'marginale toetsing' gaat om een soort procedurele toetsing waarbij de rechter niet echt aan de inhoud van een zaak toekomt. ${ }^{27}$

Wij menen dat in de combinatie van materiële en procedure toetsing verschillende (toekomstige) toetsingsmodellen kunnen worden onderscheiden. Het toetsingsmodel wordt bepaald door:

- de invulling van de wijze van materiële toetsing;

- de invulling van de wijze van procedurele toetsing; en

- de interactie tussen beide vormen van toetsing.

S. Breyer, 'The Interdependence of Science in the Law', Science (280) 1998, p. 537. Polak 1987.

K. Lenaerts, 'The European Court of Justice and Process-Oriented Review', Yearbook of European Law 2012, p. 3-16.

G.T.J.M. Jurgens, 'Marginale toetsing = procedurele toetsing? Misverstanden vanuit een buitenstaandersperspectief', NTB 2020/17. 
Daarbij gaan we ervan uit dat zowel formele als materiële beginselen altijd een rol in de toetsing van de toepassing van een discretionaire bevoegdheid (moeten) spelen.

Wat betreft de materiële toetsing onderscheiden we een drietal toetsingsvarianten:

1 De eerste variant is de meest terughoudende: de klassieke willekeurstoetsing uit het Landbouwvliegers-arrest.

2 De tweede variant vormt een indringender toetsing: de evenredigheidstoetsing (zonder willekeursluis) zoals uitgevoerd in de uitspraak over het alcoholslot.

3 De derde en laatste materiële toetsingsvariant bestaat uit een drietrapsproportionaliteitstoets waarbij de beoordeling zich uitstrekt tot de geschiktheid, de noodzakelijkheid en de evenredigheid stricto sensu van de maatregel.

Vervolgens onderscheiden we twee vormen van procedurele toetsing, namelijk (1) een toetsing óf het bestuur op enigerlei wijze onderzoek heeft gedaan naar de betrokken belangen, en of de maatregel is voorzien van een motivering die op basis van een uitwendige beoordeling steekhoudend en inhoudelijk consistent lijkt te zijn, en (2) een variant waarbij de rechter ook de betrouwbaarheid en de juistheid van de aan het onderzoek ten grondslag liggende data in zijn beoordeling betrekt, zonder overigens dat onderzoek over te doen. In dat verband kan worden gedacht aan eisen die te maken hebben met de onafhankelijkheid en onpartijdigheid van de ingeschakelde deskundigen en aan voorwaarden die kunnen worden gesteld aan de methoden van onderzoek die zijn gebruikt.

Binnen dit spectrum van procedurele en materiële toetsing is er steeds sprake van een combinatie van beide vormen. Zo is voorstelbaar dat de rechter een materieel en procedureel uiterst terughoudende toetsing verricht of juist een materieel terughoudendere toetsing compenseert met een indringender procedurele toetsing. In de meest terughoudende variant wordt een beoordeling op willekeur verbonden met de toets of het besluit voorzien is van een motivering die blijk geeft van enige verzameling van relevante gegevens en belangen. In de meest intensieve variant van algemeen verbindende voorschriften bestaat de toetsing materieel uit een drietrapsproportionaliteitsbeoordeling en worden aan de zorgvuldigheid van het onderzoek en de motivering op het punt van de geschiktheid, de noodzakelijkheid en de evenredigheid stricto sensu hoge eisen gesteld.

De interactie tussen verschillende vormen van procedurele en materiële toetsing kan echter ook tot gevolg hebben dat de intensiteit van bepaalde vormen van toetsing wordt beperkt of verscholen blijft. Gelet op de inhoud van de toetsing van de bestuursrechter heeft de Nederlandse jurisprudentie met betrekking tot de toetsing van algemeen verbindende voorschriften aan materiële beginselen al enige stappen op de intensiteitsladder gezet. De willekeursluis is verlaten wat betreft de materiële toetsing. Het evenredigheidsbeginsel, zoals dat is geformuleerd in artikel 3:4, tweede lid, Awb, wordt door de rechter toegepast. Wat betreft de toetsing aan formele beginselen echter is, gelet op de uitspraken van de $C R v B$ van 1 juli 2019 en de ABRvS van 12 februari 2020, moeilijker vast te stellen hoe 
deze plaatsvindt, omdat de 'materiële toetsingssluis' de wijze van formele toetsing verhult.

Wij vragen ons af of dat verstandig is. Gelet op het feit dat de rechter een algemeen verbindend voorschrift niet onverbindend zal verklaren of buiten toepassing zal laten op basis van een schending van formele beginselen, is het de vraag of jurisprudentiële lijnen inzake de procedurele rechtmatigheidstoetsing van algemeen verbindende voorschriften goed tot ontwikkeling kunnen komen. De rechter hoeft immers de wijze van procedurele toetsing niet goed inzichtelijk te maken, zolang deze niet tot het oordeel leidt dat ook een materieel voorschrift of een materieel beginsel wordt geschonden. Deze 'materiële toetsingssluis' zal - zo denken wij - een beperking kunnen vormen voor de ontwikkeling en verheldering - en dus de voorspelbaarheid - van de toetsing van algemeen verbindende voorschriften aan formele beginselen.

Op dit punt gekomen is het goed nog eens terug te keren naar de hiervoor door ons onderscheiden toetsingsvarianten. Wij menen dat een drietrapsproportionaliteitstoets structuur verschaft aan een rechterlijke toetsing van algemeen verbindende voorschriften die passend is in de constitutionele verhoudingen. In het kader van zo'n proportionaliteitstoets komt ook betekenis toe aan formele eisen van zorgvuldig onderzoek en een kenbare en draagkrachtige motivering. De betekenis van deze beginselen krijgt kleur door de materiële eisen die het beginsel van proportionaliteit aan de bestuurlijke besluitvorming stelt: geschiktheid, noodzakelijkheid en evenredigheid stricto sensu. ${ }^{28}$ De overwegingen van de $C R v B$ en de $\mathrm{ABRvS}$ lijken een dergelijke combinatie van een procedurele en materiële proportionaliteitstoetsing niet uit te sluiten. Zij overwegen immers dat de bestuursrechter een algemeen verbindend voorschrift buiten toepassing kan laten (en het besluit waar de procedure over gaat, vernietigen) als het voorschrift niet zorgvuldig is voorbereid of gebrekkig is gemotiveerd en de rechter om die reden dat voorschrift niet goed kan toetsen aan onder meer de algemene rechtsbeginselen of de algemene beginselen van behoorlijk bestuur. Vooralsnog zijn er in de rechtspraak echter geen tekenen dat de hoogste bestuursrechters een drietrapsproportionaliteitstoets verrichten, zoals ook voorgesteld door staatsraad advocaat-generaal Widdershoven.

\subsection{Welke factoren bepalen de indringendheid van de toetsing?}

In de uitspraken van de CRvB van 1 juli 2019 en de ABRvS van 12 februari 2020 wordt ten aanzien van de vraag waarvan de intensiteit van de beoordeling afhankelijk is, het volgende overwogen:

'De intensiteit van die beoordeling is afhankelijk van onder meer de beslissingsruimte die het vaststellend orgaan heeft, gelet op de aard en inhoud van de vaststellingsbevoegdheid en de daarbij te betrekken belangen. Die beoordeling kan materieel terughoudend zijn als de beslissingsruimte voortvloeit uit de feitelijke of technische complexiteit van de materie, dan wel als bij het 
nemen van de beslissing politiek-bestuurlijke afwegingen kunnen worden of zijn gemaakt. In dat laatste geval heeft de rechter niet de taak om de waarde of het maatschappelijk gewicht dat aan de betrokken belangen wordt toegekend naar eigen inzicht vast te stellen. Wat betreft de in acht te nemen belangen en de weging van die belangen geldt dat de beoordeling daarvan intensiever kan zijn naarmate het algemeen verbindend voorschrift meer ingrijpt in het leven van de belanghebbende(n) en daarbij fundamentele rechten aan de orde zijn.'

In de eerste plaats is de intensiteit van de beoordeling afhankelijk van de beslissingsruimte die het vaststellend orgaan heeft. De aard en de inhoud van de beslissingsruimte kunnen volgens de $C R v B$ en de $A B R v S$ worden gedefinieerd aan de hand van de politiek-bestuurlijke afwegingsruimte en de feitelijke en technische complexiteit van de materie. Met dat onderscheid appelleren de beide colleges mogelijk aan de opmerking die met name door Hirsch Ballin werd gemaakt, dat de terugtred van de wetgever lang niet altijd bedoeld is om het bestuur een beslissingsmacht met politieke speelruimte te geven, maar veel vaker berust op een praktische noodzaak en op de complexiteit van de beslissituaties, in de verwachting dat de verdere uitwerking en toepassing wel politiek moeten worden verantwoord, maar niet zelf politiek van aard zijn. ${ }^{29}$

De vraag is echter waarom de aard van de beslissingsvrijheid de intensiteit van de toetsing bepaalt. Het enige wat de beide colleges daarover zeggen, is dat in het geval van een politiek-bestuurlijke afwegingsruimte de rechter niet de taak heeft om de waarde of het maatschappelijk gewicht dat aan de betrokken belangen wordt toegekend naar eigen inzicht vast te stellen. Dat lijkt ons juist, maar het is ook een open deur. De rechter heeft immers tot taak het besluit te toetsen, en dat is nu eenmaal niet hetzelfde als zelf te besluiten.

Wij denken met Hirsch Ballin dat waar het gaat om de rechterlijke toetsing van algemeen verbindende voorschriften het niet een keuze is uit hetzij een aan geregelde onafhankelijke rechterlijke toetsing nagenoeg onttrokken bestuurlijk machtsbereik, hetzij rechterlijk activisme dat het (door de wetgever beoogde) bestuurlijke primaat in de nadere beoordeling tenietdoet. Uitgangspunt is dat rechterlijke toetsing geen overnemen van verantwoordelijkheid is; het bestuur beslist, niet de rechter. ${ }^{30}$ Eigen aan de rechterlijke rechtmatigheidstoetsing is dat dit met een zekere distantie gebeurt in situaties waarin er beslissingsruimte bestaat voor het bestuur, in die zin dat de rechterlijke toetsing zich richt op de rechtsregels en -beginselen die de beslissingsruimte normeren, en niet op de doelmatigheid van de door het bestuur te verrichten beoordelingen en belangenafwegingen. Terughoudendheid is dus eigen aan een rechtmatigheidstoetsing van de beslissingsruimte. Omdat er bovendien sprake is van beslissingsruimte vindt de toetsing niet (enkel) plaats aan de hand van hogere rechtsregels, maar vooral aan de hand van beginselen. Als gelet op het bestaan van duidelijke voorschriften van hogere orde er geen beslissingsruimte voor de regelgever was, hoefde de rechter 
ook niet aan rechtsbeginselen te toetsen. Deze beginselen zijn waarden die het bestuur moet meewegen in zijn besluitvorming, zonder dat de exacte uitkomst daarvan duidelijk is. Alleen het bestuur kan in zijn besluit een optimalisatie van die beginselen aanbrengen. De rechter doet deze optimalisatie niet over. Hij beoordeelt slechts of (al) de beginselen in acht zijn genomen.

De intensiteit van de toetsing aan beginselen kan daarom, naar onze mening, ook niet opnieuw afhankelijk worden gesteld van de mate waarin sprake is van beslissingsvrijheid. De mate van beslissingsvrijheid bepaalt slechts in hoeverre - mede bij afwezigheid van normering door een hogere wetgever - beginselen bij de beoordeling van de rechtmatigheid een rol spelen en zou dus niet ook nog eens moeten bepalen hoe indringend die toetsing aan beginselen is.

De aard van de materie, zoals de politieke gevoeligheid en de technische aard, zou nadrukkelijk wel een rol moeten spelen bij de vaststelling van de omvang van de beslissingsruimte. Een beslissing die bij de wetgever ligt. Zo zou in politiek gevoelige materie bij voorkeur niet door een bestuurswetgever moeten worden beslist, die niet kan bogen op een eigen democratische legitimatie. Bij sterk technische materie kan in ruimere mate aan die bestuurswetgever worden gedelegeerd, mits - zo zouden wij denken - de basisnorm maar door het rechtstreeks democratisch gelegitimeerde gezag wordt bepaald. Deze aard van de materie bepaalt dan echter niet ook nog eens de intensiteit van de toetsing.

Daarmee zijn we meteen aangekomen bij de vraag waarover advocaat-generaal Widdershoven wel, maar de ABRvS niet rept: is de democratische legitimatie van het bestuursorgaan een factor die de indringendheid van de toetsing moet bepalen? Naar ons oordeel is daarvoor geen reden. De aard en inhoud van de te nemen beslissingen moeten ons inziens een rol spelen bij de vraag welk orgaan welke bevoegdheid binnen welke grenzen zou moeten uitoefenen. Als de rechter echter, gelet op de wettelijke grondslag, vaststelt dat een bestuursorgaan bevoegd was om een besluit te nemen, zou dit voor de wijze van toetsing van het gebruik van de beslissingsvrijheid een gegeven moeten zijn. In dat kader past het naar onze mening niet om de intensiteit van de beoordeling van het algemeen verbindend voorschrift aan rechtsbeginselen vervolgens te laten afhangen van de democratische legitimiteit van het bestuursorgaan. Wij vermoeden dan ook dat dit aspect daarom in de uitspraken niet aan de orde komt.

Wel zijn we het met de ABRvS eens dat de aard van het geschonden belang en de omvang van de schending van dat belang de intensiteit van de toetsing zouden moeten bepalen. Naarmate een algemeen verbindend voorschrift een grotere inbreuk maakt op de fundamentele rechten van burgers, is er aanleiding om de rechtmatigheidstoetsing te intensiveren. Hier komen de toetsing aan algemene beginselen van behoorlijk bestuur en de toetsing aan grondrechten samen. Waar er sprake is van schending van grondrechten, is er - en was er ook al vóór de genoemde uitspraken van de bestuursrechter door middel van grondrechtentoetsing aan het Europees Verdrag tot bescherming van de rechten van de mens en de fundamentele vrijheden (EVRM) - al sprake van indringendere materiële toetsing op noodzaak en evenredigheid. Ook de toetsing aan het formele zorgvuldigheidsbeginsel en het motiveringsbeginsel zou naar onze mening in geval van een inbreuk op grondrechten indringender moeten plaatsvinden. 


\section{Gevolgen van de uitspraken van de bestuursrechter voor de bestuurswetgever}

\subsection{De juridische rationaliteit in het wetgevingsproces}

In het wetgevingsproces is rechtmatigheid een belangrijk uitgangspunt, maar allerminst het enige. In de literatuur over wetgeving wordt sinds lange tijd een onderscheid gemaakt tussen verschillende rationaliteiten die het wetgevingsproces beheersen. ${ }^{31}$ Rationaliteiten duiden hier op de passende beleids- en handelingstheorieën ten behoeve van de totstandkoming van beleid en wetgeving. Deze rationaliteiten bepalen derhalve de wijze van de beleidsvorming c.q. de belangenafweging van de wetgever.

Grosso modo wordt daarbij een onderscheid gemaakt tussen een politieke rationaliteit, een juridische rationaliteit en een technische (of empirische/wetenschappelijke) rationaliteit. Waar vanuit de juridische rationaliteit wordt getracht te waarborgen dat algemeen verbindende voorschriften tot stand komen die in overeenstemming zijn met het recht, wordt vanuit de politieke rationaliteit geprobeerd om algemeen verbindende voorschriften vast te stellen die tegemoetkomen aan de politieke doelstellingen van de regelgever. De technische rationaliteit probeert - vanuit de kennis die is opgebouwd in verschillende wetenschappen, zoals economie, sociologie en natuurwetenschappen - maatregelen te realiseren die effectief en efficiënt zijn vanuit vastgestelde maatschappelijke problemen en die tegelijkertijd zo min mogelijk gevolgen hebben voor andere processen binnen de samenleving.

In de literatuur over wetgeving is de teneur dat de juridische rationaliteit en de technische rationaliteit moeite hebben relevant te blijven in het overwegend politieke wetgevingsproces. ${ }^{32}$ De politieke overtuiging dat een maatschappelijk probleem bestaat en dit een specifieke wettelijke maatregel vergt, steunt niet altijd op een duidelijke empirische onderbouwing en is niet altijd gestoeld op een goed onderbouwde sturingsfilosofie. Bij de vorming van kabinetten en bestuurscolleges wordt onderhandeld over prioritaire beleidsdoelstellingen, die uiteindelijk worden vastgelegd in akkoorden die gedurende de bestuursperiode voor een deel door middel van regelgeving dienen te worden gerealiseerd. Daarbij worden soms afspraken gemaakt over maatregelen die eerder een compromis zijn dan een heldere keuze voor een bepaalde wijze van interventie. Bestuurders worden vervolgens aan het eind van hun bestuurstermijn deels afgerekend op het behalen van 'hun' doelstellingen die in akkoorden zijn opgenomen, en dus voor een aanmerkelijk deel op de regelgeving die tot stand is gebracht. Dit leidt ertoe dat het beleidsproces binnen het ondersteunend ambtelijk apparaat vooral is gericht op de tijdige vaststelling van de in de bestuurscoalitie overeengekomen maatregelen. Ook de druk die bij incidenten vanuit de maatschappij en de media op politici

31 I.Th. Snellen, Boeiend en geboeid. Ambivalenties en ambities in de bestuurskunde (oratie Tilburg), Alphen aan den Rijn: Samsom H.D. Tjeenk Willink 1987.

32 Zie bijv. G.J. Veerman, Over wetgeving, principes, paradoxen en praktische beschouwingen, Den Haag: Sdu Uitgevers 2007, hoofdstuk 8 en R.A.J. van Gestel, 'De wetgevingsjurist: croupier of poortwachter?', $A$ A 2020, p. 316-317. 
wordt gelegd om op korte termijn te interveniëren, leidt ertoe dat politici de neiging hebben om vooral snel en doortastend met wettelijke maatregelen op te treden. ${ }^{33}$

Waar binnen de volksvertegenwoordiging en het bestuur een proces plaatsheeft om politieke doelstellingen zo snel mogelijk in wettelijke maatregelen om te zetten, blijkt het lastig voor (wetgevings)juristen om ervoor te zorgen dat relevante feiten en belangen worden verzameld en de belangen op evenredige wijze worden afgewogen. Het wetgevingsproces is vooral een race tegen de klok. Het aantal ambtenaren met een juridische achtergrond is daarnaast in de loop der jaren verhoudingsgewijs afgenomen. De terughoudende rol van de rechter en daarmee het grotendeels ontbreken van een externe juridische tegenmacht die de bestuurswetgever dwingt om juridische maatstaven in acht te nemen, maakt de opgave voor de juristen om de juridische kwaliteit te waarborgen niet eenvoudiger. ${ }^{34}$

Een belangrijk aandachtspunt bij de totstandkoming van regelgeving is vervolgens welk redelijk evenwicht vanuit de juridische rationaliteit kan worden gevonden tussen politieke rationaliteit en technische rationaliteit. Dient een wettelijke regel een redelijk verband te houden met de werkelijkheid? Welke mate van onderbouwing vraagt het recht van de effecten van een voorgestane wettelijke maatregel? Gaat het erom dat de regelgever in de toelichting bij de wetgevende handeling slechts 'een beeld' schetst van het maatschappelijk probleem en de gevolgen van de voorgestane maatregel? Of dient de bestuurswetgever een maatschappelijk probleem en de effecten van de te onderbouwen maatregel te kunnen onderbouwen met wetenschappelijke onderzoekingen en feitenonderzoek? Het is enerzijds realistisch om vast te stellen dat de keuze voor de wijze van overheidsinterventie en daarmee de vaststelling van wetgeving (nog) geen exacte wetenschap is. Anderzijds is het in deze tijd moeilijk te accepteren dat de wetgever in het geheel geen empirische onderbouwing geeft voor de inhoud van het algemeen verbindend voorschrift.

\subsection{De gevolgen van de uitspraken van de bestuursrechter voor de bestuurswetgever}

De uitspraken van de $C R v B$ en de ABRvS hebben tot gevolg dat algemeen verbindende voorschriften van de bestuurswetgever rechtstreeks worden getoetst op schending van algemene beginselen van behoorlijk bestuur en algemene rechtsbeginselen. Hiermee neemt het aantal criteria toe waaraan de rechter het totstandkomingsproces van regelgeving en de afweging van de bestuurswetgever toetst. Met name de rechtstreekse beoordeling van regelgeving aan het evenredigheidsbeginsel, en mogelijk over de band van het evenredigheidsbeginsel, het zorgvuldigheidsbeginsel en het motiveringsbeginsel, kan een belangrijke rol gaan spelen. De exceptieve toetsing van het algemeen verbindend voorschrift aan het ongeschreven recht zal mogelijk - afhankelijk van de aard van de indringende toet-

33 Dit wordt tegenwoordig de risico-regelreflex genoemd. Zie bijv. R. van den Dikkenberg, 'Ik mis wel eens de conclusie dat iets gewoon pech is', Stcrt. 2014, 45.

34 Bijv. W. Wierenga, 'Met recht positie kiezen in een politiek-bestuurlijke omgeving. Omgaan met de spanning tussen rechtsstatelijke waarden en politiek-bestuurlijke wensen', RegelMaat 2020, afl. 4 , p. 232-243. 
sing - strenger zijn. Deze exceptieve toetsing zal zich mogelijk ook vaker voor gaan doen. Indien rechtssubjecten immers de kansen op een succesvol beroep op de onrechtmatigheid van wettelijke voorschriften zien toenemen, zullen zij mogelijk ook de rechtmatigheid van het algemeen verbindend voorschrift vaker in juridische procedures aan de orde stellen.

Dit roept de vraag op hoe kwetsbaar algemeen verbindende voorschriften eigenlijk zijn bij een indringende rechterlijke toetsing aan het motiverings-, zorgvuldigheids- en evenredigheidsbeginsel. Dit heeft niet alleen te maken met het (soms) ondergeschikte belang van rechtmatigheid in het regelgevingsproces. De ex-antebeoordeling van de evenredigheid van een algemeen verbindend voorschrift brengt, gelet op de aard van algemeen verbindende voorschriften, in de praktijk bijzondere uitdagingen mee.

De vaststelling van algemeen verbindende voorschriften wijkt in zoverre af van de vaststelling van veel andere besluiten, zoals beschikkingen, dat de keuze voor de wijze van interventie - het instrument - vaak nog openstaat. Dit geldt vanzelfsprekend voor wetten in formele zin, maar ook voor veel bestuurswetgeving. Deze wordt op basis van de autonome bevoegdheid van decentrale regelgevers vastgesteld of op basis van vaak zeer ruime delegatiegrondslagen van wetten in formele zin. Het feit dat men voorschriften mag stellen, geeft nog geen beeld van de wenselijkheid, de aard en de gevolgen van deze voorschriften. Dit betekent dat de verzameling van de relevante feiten en belangen in het kader van de uitoefening van de bevoegdheid niet alleen ziet op de zwaarte van de in het voorschrift opgenomen verplichtingen, maar vaak ook nog op de vaststelling van het maatschappelijk belang, het onderzoek van de noodzaak van interventie en de keuze voor een bepaalde manier van interventie. Van de vaststelling van het maatschappelijk belang dat aan interventie ten grondslag ligt, mag worden aangenomen dat dit bij uitstek een politieke keuze is die in beginsel niet door de rechter zal worden beoordeeld. Dit geldt echter in mindere mate voor de noodzaak van interventie en de keuze voor de wijze van interventie.

Als gevolg van het algemene karakter zal de bestuurswetgever bovendien de evenredigheid van het algemeen voorschrift in principe alleen in abstracto kunnen beoordelen. Als een regel van toepassing is op vele honderden of vele duizenden individuele gevallen zal de regelgever in de praktijk niet in staat zijn om de specifieke gevolgen van een maatregel voor individuele burgers te onderzoeken. Hij zal moeten uitgaan van een of meer normgroepen om de evenredigheid van het voorschrift te beoordelen. De regelgever zal echter ook terughoudend moeten zijn met een te grote afstemming van wettelijke regels op groepen met verschillende kenmerken. Te vergaande detaillering gaat immers ten koste van de eenvoud, transparantie (rechtszekerheid) en uitvoerbaarheid van de regelgeving. Tot slot zal de regelgever in veel gevallen geen onderscheid willen of kunnen maken, omdat hij juist beoogt een voorschrift vast te stellen dat voor iedereen geldt. Politiek en maatschappelijk zijn uitzonderingen op regels, zoals op het terrein van volksgezondheid en verkeersveiligheid, vaak helemaal niet wenselijk.

Het is daarom voor de regelgever een belangrijke vraag in hoeverre de rechter de onrechtmatigheid van een voorschrift zal willen vaststellen enkel op basis van het feit dat de regelgever de bijzondere omstandigheden van een bepaald persoon of 
een bepaalde groep van personen niet of onvoldoende heeft meegewogen. Een door de rechter opgelegde, te vergaande onderzoeksplicht kan de effectiviteit van wetgeving aanzienlijk ondergraven. Hetzelfde geldt als de rechter relatief vaak besluit wetgeving buiten toepassing te laten of onverbindend te verklaren. Het is mogelijk uit rechtsbeschermingsperspectief aanlokkelijk om elk algemeen verbindend voorschrift als een bundel beschikkingen te beschouwen, uit het oogpunt van het ordenend karakter van regelgeving is dat minder wenselijk.

De afgelopen jaren wordt ervoor gepleit om het burgerperspectief c.q. de menselijke maat meer nadrukkelijk terug te brengen in de uitvoering. Zo wordt ervoor gepleit dat altijd afwijking van wettelijke regels mogelijk moet zijn, mits de bijzondere omstandigheden daartoe noodzaken. Voor de bestuurswetgever kan dit als belangrijk voordeel hebben dat een buitenproportioneel gevolg van een wettelijk voorschrift in het individuele geval niet hoeft te leiden tot onrechtmatigheid van het voorschrift. ${ }^{35}$ In de uitvoering zal in beginsel elke onevenredigheid in het individuele geval kunnen worden gecorrigeerd. Tegelijkertijd zal een dergelijke vaste discretionaire ruimte uit het oogpunt van de uitvoerbaarheid en handhaafbaarheid van wetgeving, de rechtsgelijkheid en het voorkomen van juridische procedures minder wenselijk zijn. ${ }^{36}$ Het risico bestaat dat de vraag in welke gevallen al dan niet van de algemeen verbindende voorschriften zou moeten worden afgeweken, voortdurend in procedures aan de orde kan komen. ${ }^{37}$

De herhaaldelijke toepassing van een algemeen verbindend voorschrift brengt daarnaast mee dat een voorschrift in de loop der tijd op andere personen van toepassing zal worden dan wel in de loop der tijd minder, of juist meer, belastend kan worden voor bepaalde groepen van betrokkenen. Dit kan ook gevolgen hebben voor de rechtmatigheid van het voorschrift. De mogelijkheid van een exceptief verweer met betrekking tot algemeen verbindende voorschriften wordt immers niet beperkt door het verlopen van bezwaar- en beroepstermijnen. Het is daarbij de vraag in hoeverre de rechter de onrechtmatigheid van een voorschrift zal willen vaststellen op grond van kennis die op het moment van vaststelling van het algemeen voorschrift nog niet of niet in diezelfde mate beschikbaar was. Dient de rechter uitsluitend te kijken naar de rechtmatigheid ex tunc of kunnen daarbij latere ontwikkelingen ook aan de orde komen? Zo spreekt advocaat-generaal Widdershoven in dit verband van de 'benefit of the hindsight' (of retrospec-

35 Scheltema stelt in dit kader voor om in de Awb de volgende bepalingen op te nemen: 'Indien de toepassing van een wettelijke regel leidt tot nadelige gevolgen die onevenredig zijn in verhouding tot de met die regel te dienen doelen, en de belanghebbende hiervan geen verwijt kan worden gemaakt, kan van de regel worden afgeweken voor zover dat nodig is om tot een meer evenwichtige regeltoepassing te komen.' M. Scheltema, 'Wetgeving in de responsieve rechtsstaat', RegelMaat 2018, afl. 3, p. 120-131. Zie in dit verband ook ABRvS 23 oktober 2019, ECLI:NL:RVS: 2019:3536, waarin de ABRvS als het ware 'omgaat' door in een regeling die tot dan toe imperatief werd uitgelegd, een discretionaire ruimte voor het bestuur te lezen.

36 Zie bijv. Ar 2.8: 'Een regeling wordt op zodanige wijze ingericht dat zij zo weinig mogelijk conflicten oproept. Daartoe wordt onder meer aan het volgende voldaan: a. het aantal beslismomenten waartoe toepassing van de regeling aanleiding geeft, wordt tot een minimum beperkt; (...).'

37 Zie ook Ar 5.25, waarin wordt opgedragen grote terughoudendheid te betrachten bij de toepassing van hardheidsclausules. 
tieve ex-tunctoetsing ${ }^{38}$ ), waarbij de rechter bij de beoordeling van een algemeen verbindend voorschrift mede gebruik maakt van informatie die hij heeft verzameld uit eerdere zaken die hem zijn voorgelegd. ${ }^{39}$ Voor de bestuurswetgever komt een dergelijk onrechtmatigheidsoordeel met de 'benefit of the hindsight', ook al gaat het enkel om nieuwe informatie over de gevolgen van een voorschrift in individuele gevallen, dicht in de buurt van een toetsing ex nunc, waarbij de rechter een algemeen verbindend voorschrift van toen toetst met zijn kennis van nu. ${ }^{40}$

De vraag is tot slot ook hoe zwaar de maatstaven zullen zijn die de rechter aan het feitenonderzoek en de motivering van de maatregel zal stellen. Met welke bewijsmiddelen dient de bestuurswetgever de vaststelling van de effectiviteit en noodzakelijkheid van de maatregel te kunnen onderbouwen? Dient de bestuurswetgever slechts de sturingsfilosofie van de maatregel in algemene bewoordingen uiteen te zetten, of dient deze sturingsfilosofie ook een basis te hebben in een wetenschappelijk gestaafde theorie en empirisch onderzoek? Is een globaal onderzoek naar de effecten van een regeling door betrokken ambtenaren of een willekeurig extern adviesbureau afdoende, of dienen de effecten van de maatregel voor alle betrokkenen met wetenschappelijk gevalideerde onderzoeksgegevens te worden onderbouwd?

\subsection{Kan het wetgevingsbeleid fungeren als kader voor rechtmatigheidstoetsing?}

$\mathrm{Nu}$ de willekeursluis niet langer bestaat, zal mogelijk de druk op de bestuurswetgever om de eigen rechtmatigheidsbeoordeling binnen het wetgevingsproces beter inzichtelijk te maken en te versterken groter worden. Door een betere exantebeoordeling van de rechtmatigheid door de bestuurswetgever in het wetgevingsproces kan immers worden voorkomen dat rechterlijke uitspraken later in de weg staan aan adequate toepassing van eenmaal vastgestelde regelgeving. De juridische rationaliteit kan daarmee binnen het wetgevingsproces aan belang winnen.

Tot op heden stelde het recht slechts een beperkt aantal harde eisen aan bestuurswetgeving. De normering van wetgeving is - mogelijk mede daarom vooral neergelegd in beleidsdocumenten, toetsen en handreikingen, die samen het wetgevingsbeleid vormen. Dit wetgevingsbeleid, dat vooral op centraal niveau tot stand is gekomen, is voor de (departementale) wetgevingsambtenaren een leidend inhoudelijk en procedureel kader voor de vaststelling van algemeen verbindende voorschriften en geeft daarmee ook inkleuring aan de ex-anterechtmatigheidsbeoordeling die zij bij de voorbereiding van wetgeving moeten uitvoeren.

De vraag is daarmee of het wetgevingsbeleid dat binnen het Rijk de afgelopen decennia tot ontwikkeling is gekomen, een rol kan spelen bij de toekomstige rechtmatigheidsbeoordeling van wetgeving. Hierbij is enerzijds aan de orde in hoeverre een nauwgezette toepassing van dit beleid voorkomt dat wetgeving door de rechter onrechtmatig wordt geoordeeld. Anderzijds is het de vraag in hoeverre 
de rechter, om de beoordeling van de rechtmatigheid van algemeen verbindende voorschriften verder te operationaliseren, zou willen aansluiten bij criteria en procesvereisten die in het wetgevingsbeleid zijn neergelegd. Een dergelijke benadering zou aansluiten bij ontwikkelingen in de Europese rechtspraak, waarbij een grotere aandacht voor het evidencebased karakter van wettelijke voorschriften zich vertaalt in een beoordeling of bij de voorbereiding van wetgeving alle procedurele richtlijnen wel zijn gevolgd. ${ }^{41}$ Daarbij is bovendien van belang dat een meer procedurele beoordeling van de zorgvuldige totstandkoming van regelgeving voor de rechter een alternatief kan vormen voor een (politiek gevoeligere) inhoudelijke beoordeling van de evenredigheid van het algemeen verbindend voorschrift in het concrete geval. Randvoorwaarde is dan wel dat het wetgevingsbeleid een objectieve standaard vormt voor een adequate ex-anterechtmatigheidstoetsing van wettelijke voorschriften. In dat licht is het zaak om het wetgevingsbeleid nader te bestuderen.

Overeenkomstig het rijkswetgevingsbeleid, dat grotendeels is neergelegd in de Aanwijzingen voor de regelgeving en het Integraal Afwegingskader voor beleid en regelgeving (IAK), zal de bestuurswetgever kennis moeten vergaren over de relevante feiten en omstandigheden met betrekking tot het bewuste onderwerp, het probleem moeten omschrijven dat aanleiding geeft tot interventie, moeten aangeven met welk doel hij intervenieert, en alleen tot wetgeving moeten besluiten indien de noodzaak daarvan is komen vast te staan. ${ }^{42}$ Daarbij zal hij moeten aangeven of het probleem niet beter kan worden opgelost door betrokkenen zelf, door middel van andere maatregelen dan wetgeving of minder ingrijpende vormen van wetgeving (bijvoorbeeld door aansluiting bij het zelfregulerend vermogen, gebruik van andersoortige instrumenten of minder ingrijpende regels). Hij zal moeten beoordelen of de regels uitvoerbaar en handhaafbaar zijn, welke neveneffecten zij sorteren en welke lasten, zoals nalevingskosten, administratieve lasten en inbreuken op grondrechten, zij meebrengen voor betrokkenen en de samenleving in haar geheel. Daarbij zal hij ook moeten beoordelen hoe de regel past binnen het geheel van wettelijke regels, en of de regel een bestendig karakter zal hebben. Tot slot dient hij de baten van de voorgenomen wettelijke regel af te wegen tegen de lasten en moet hij beoordelen of de nadelige gevolgen niet onevenredig zijn in verhouding tot de daarmee te dienen doelen. ${ }^{43}$ Deze criteria geven daarmee invulling aan een zorgvuldige voorbereiding van het algemeen verbindend voorschrift en een ex-antebeoordeling van evenredigheid. Zij zijn meer in het bijzonder gericht op een onderzoek naar en onderbouwing van de geschiktheid (effectiviteit), noodzaak (subsidiariteit) en algemene gevolgen van een maatregel, die bij de evenredigheidstoetsing een rol kunnen spelen. Deze eisen dienen in de toelichting bij de regeling aan de orde te komen. ${ }^{44}$

41 Zie bijv. R.A.J. van Gestel, 'De rechter als wetgevingswaakhond', RegelMaat 2017, afl. 2, p. 115-130.

42 Zie met name Ar 2.3.

43 Ar 2.11.

44 Ar 4.43. 
In het wetgevingsbeleid zijn daarnaast instrumenten en toetsen ontwikkeld om een adequate ex-antebeoordeling van wetgeving op basis van bovengenoemde criteria mogelijk te maken. Het gaat daarbij om een variëteit aan toetsen, zoals een bedrijfseffectentoets, een mkb-toets, een milieueffectentoets, een kader voor de doorberekening van toelatings- en handhavingskosten, een Privacy Impact Assessment, een algemene leidraad voor maatschappelijke kosten-batenanalyse (speciaal ontwikkeld om evidencebased beleid te maken ${ }^{45}$ ), een uitvoerbaarheidsen handhaafbaarheidstoets en een doenvermogentoets. Al deze toetsen bieden derhalve gegevens die kunnen bijdragen aan de ex-antebeoordeling van het algemeen verbindend voorschrift.

Tot slot zijn er overeenkomstig het wetgevingsbeleid verschillende instanties die bekijken of de verschillende criteria bij de voorbereiding van regelgeving goed zijn toegepast, zoals de sector Juridische Zaken en Wetgevingsbeleid van het Ministerie van Justitie en Veiligheid, het Adviescollege toetsing regeldruk en verschillende afdelingen van de departementen van Binnenlandse Zaken en Koninkrijksrelaties, Economische Zaken en Klimaat en Financiën.

Het wetgevingsbeleid biedt daarmee een breed kader waarmee de bestuurswetgever invulling kan geven aan de ex-antebeoordeling van wetgeving. De adequate toepassing van dit kader helpt de bestuurswetgever om rechtmatige wetgeving te maken. Maar zal het wetgevingsbeleid ook voor de rechter relevant kunnen zijn bij de rechtmatigheidstoetsing van wetgeving? Dat is niet vanzelfsprekend.

Ten eerste is het wetgevingsbeleid een beleid dat zich slechts over een deel van de overheid uitstrekt. De Aanwijzingen voor de regelgeving en het IAK hebben betrekking op wetgeving die of beleid dat onder verantwoordelijkheid van de ministers wordt ontwikkeld en binden die ministers en de onder hen werkende ambtenaren. Een deel van de kaders werkt ook in enige mate door naar andere organen van de centrale overheid, zoals het parlement, de Afdeling advisering van de Raad van State en zelfstandige bestuursorganen. Deze organen zijn niet aan de Aanwijzingen en het IAK gebonden, maar houden daar, in hun toetsingskaders of hun handelingspraktijk, in zekere mate rekening mee. Het nationale beleid werkt in zekere zin ook door naar decentrale overheden. Deze zijn niet aan de Aanwijzingen of het IAK gehouden, maar kunnen daarvan wel gebruik maken. Zo wordt in 100 Ideeën voor de gemeentelijke regelgever veelvuldig aan de Aanwijzingen gerefereerd. ${ }^{46}$ Daarmee is het wetgevingsbeleid echter nog geen algemene nationale standaard. De rechter zal alleen de regering en ministers aan het wetgevingsbeleid kunnen houden.

Ten tweede is wetgevingsbeleid nadrukkelijk beleid. Het betreft beleid over de kwaliteitskenmerken die met betrekking tot wetgeving worden gesteld en over het gebruik van toetsen die de naleving van die kwaliteitskenmerken moeten waarborgen. Als gevolg van de terughoudende beoordeling van algemeen verbindende voorschriften door de rechter en - daarmee - de (tot voor kort) beperkte normering vanuit het ongeschreven recht is dit beleid de bovenliggende factor voor de normering van de totstandkoming van wetgeving in Nederland. Niet alle 
onderdelen van het IAK zijn echter even stevig ingebed in de regelgevingspraktijk. Slechts een deel van de gehanteerde toetsen wordt beschouwd als 'verplichte' toetsen. Bovendien kan de bestuurswetgever van het beleid afwijken, als hij dat nodig vindt. ${ }^{47}$ Waar de bestuurswetgever zich niet altijd gebonden acht aan de toepassing van alle onderdelen van het beleid, is het de vraag of de rechter daaruit een harde kern kan en wil selecteren, waarmee hij zijn rechtmatigheidstoetsing handen en voeten kan geven.

Ten derde is wetgevingsbeleid niet alleen gericht op juridische kwaliteit van wetgeving. De Aanwijzingen en het IAK bevatten een mix van de verschillende rationaliteiten die betrokken zijn in het wetgevingsproces. Zij bevatten de overlevering - het destillaat - van allerlei beleid dat tot op heden met betrekking tot wetgeving is gevoerd. Soms was dat beleid sterk gericht op de verwerkelijking van het recht (bijvoorbeeld de nota 'Zicht op wetgeving' ${ }^{48}$ ), soms was dat vooral gericht op economische groei en vermindering van administratieve lasten voor burger en bedrijven (zie bijvoorbeeld de operatie 'Marktwerking, Deregulering en Wetgevingskwaliteit ${ }^{\text {'49 }}$ ), en soms is dat beleid gericht op de ondersteuning van de onmachtige burger (doenvermogentoets ${ }^{50}$ ). Rechtmatigheid is daarmee een van de vele aandachtspunten. Uit het oogpunt van integrale besluitvorming is een dergelijk meerzijdig perspectief van grote waarde. Ook vanuit het recht bezien heeft deze multidisciplinaire benadering het voordeel dat in het wetgevingsbeleid maatstaven zijn ontwikkeld als noodzaak, subsidiariteit en efficiëntie, die niet een zuiver juridisch belang hebben, maar wel nadere invulling zouden kunnen geven aan een toetsing aan rechtsbeginselen, zoals het evenredigheidsbeginsel. Nadeel van dit multidisciplinair karakter van het wetgevingsbeleid is echter dat de juridische relevante gedeelten niet altijd even gemakkelijk te herkennen zijn. De rechter die bijvoorbeeld zoekt naar een eenvoudig hanteerbaar juridisch relevant kader als maatstaf voor een nadere invulling van de formele zorgvuldigheid of voor de evenredigheidsbeoordeling, zal dit in het huidige beleid niet goed terugvinden.

Tot slot is nog maar de vraag wat de kwaliteit is van het huidige wetgevingsbeleid. Waar de Haagse gemeenschap van departementale wetgevingsjuristen het als vanzelfsprekend kader hanteert bij de voorbereiding van regelgeving, blijft de kwaliteit van het wetgevingskwaliteitsbeleid niet onbesproken. De Organisation for Economic Co-operation and Development (OECD) gaf onlangs aan dat het IAK onvoldoende transparant is voor belanghebbenden, geen integraal deel uitmaakt van het besluitvormingsproces binnen de regering en te laat in het beleidsvormingsproces wordt toegepast. ${ }^{51}$ Ook is het toezicht op de toepassing van het IAK

\section{Zie bijv. Ar 1.2, tweede lid.}

Kamerstukken II 1990/91, 22008, nr. 1.

Kamerstukken II 1994/95, 24036, nr. 1.

Kamerstukken II 2017/18, 34775 VI, nr. 88.

OECD, Ex Ante Regulatory Impact Assessment in the Netherlands, 2020. Maar zie ook C. Riezebos \& M.H.A.F. Lokin, 'Voorbereiden van wetgeving: legislative manoeuvres in the dark', RegelMaat 2012, afl. 1, p. 3-16, A.C.M. Meuwese, "Waarom het IAK het keurmerk "IA" (nog) niet mag voeren', RegelMaat 2012, afl. 1, p. 17-28 en R.A.J. van Gestel, 'Wetgeving en de toets der kritiek', RegelMaat 2018, afl. 4, p. 177-193. 
onvoldoende ontwikkeld en ontbreekt het in het beleid aan heldere doelstellingen. Moet de rechter dan wel kijken naar dit wetgevingsbeleid als maatstaf voor de kwaliteit van wetgeving en daarmee als een adequaat referentiekader voor de beoordeling van de zorgvuldigheid en evenredigheid van wetgeving?

Daarmee kan voorzichtig worden geconcludeerd dat het wetgevingsbeleid weliswaar een belangrijk kader vormt voor de beleidsmaker en bestuurswetgever binnen de rijksoverheid om de gevolgen van wetgeving in kaart te brengen, maar dat het onwaarschijnlijk is dat de rechter de toepassing van het geheel van procedures en toetsen dat onderdeel uitmaakt van het wetgevingsbeleid als indicatie zal beschouwen voor het feit dat de wetgeving zorgvuldig tot stand is gekomen en rechtmatig is. Daarvoor is het huidige beleid onvoldoende transparant en bestaat er te veel onzekerheid over de uiteindelijke waarde daarvan. Ook is nog maar de vraag of dit geheel van toetsingskaders voor andere bestuurswetgevers wel goed toepasbaar is. Dat betekent niet dat de rechter aan alle aspecten van het wetgevingsbeleid voorbij hoeft te gaan. Zo zou bijvoorbeeld het ontbreken van de bespreking van de resultaten van een internetconsultatie in de toelichting bij een regeling als indicatie kunnen worden gezien dat de verschillende belangen bij een wettelijke regeling in de voorbereiding daarvan onvoldoende in kaart zijn gebracht. Waarschijnlijker is echter dat de rechter grotendeels zijn eigen maatstaven zal ontwikkelen en de voorgelegde regelingen daaraan zal toetsen.

\section{Conclusie}

Ons Nederlands bestuursrecht is, zoals Scheltema opmerkt, in die zin slecht ontwikkeld, dat er weinig aandacht is geweest voor rulemaking als onderdeel van het bestuursrecht. ${ }^{52}$ Onder meer de uitsluiting van het directe beroep tegen algemeen verbindende voorschriften in artikel 8:3 Awb en de 'willekeursluis' bij de toetsing aan algemeen verbindende voorschriften hebben ertoe bijgedragen dat vanuit de rechtspraak weinig criteria zijn ontwikkeld voor de besluitvorming over regelgeving.

Mogelijk komt hierin verandering. Als gevolg van de uitspraken van de $C R v B$ van 1 juli 2019 en de ABRvS van 12 februari 2020 zal de bestuursrechter algemeen verbindende voorschriften indringender gaan toetsen aan het ongeschreven recht. De willekeursluis is in deze uitspraken verlaten. De rechter zal in ieder geval aan alle materiële rechtsbeginselen toetsen. Wat dit precies betekent voor de bestuurswetgever is vooralsnog onduidelijk. In principe zou een toetsing van algemeen verbindende voorschriften aan meer materiële beginselen dan het verbod van willekeur ertoe kunnen leiden dat de rechtmatigheid van wetgeving meer nauwgezet wordt beoordeeld en de onrechtmatigheid vaker zou kunnen worden uitgesproken. Of dit ook daadwerkelijk het geval zal zijn, is niet goed te voorspellen.

52 M. Scheltema, 'Internationale regelgeving buiten de staten om: de behoefte aan bestuursrechtelijke beginselen over regelgeving', NTB 2014/28. 
In het bovenstaande hebben wij betoogd dat de indringendheid van toetsing aan rechtsbeginselen en algemene beginselen van behoorlijk bestuur steeds wordt bepaald door een combinatie van verschillende wijzen van toetsing aan formele en materiële beginselen. Materieel kan meer of minder indringend worden getoetst door meer of andere inhoudelijke maatstaven toe te passen. Dit hebben wij geillustreerd met ontwikkelingen rond de toetsing van het evenredigheidsbeginsel. Zo ook kunnen verschillende maatstaven worden gehanteerd voor de wijze van verzameling van feiten en belangen of de motivering. Het is echter de combinatie van beide vormen van toetsing die uiteindelijk de indringendheid van de toetsing bepaalt.

Wij menen dat zowel de rechtspraak als de wetgevingspraktijk gebaat is bij een heldere en voorspelbare manier van toetsing door de rechter. In dat kader is het jammer dat voor formele beginselen de willekeursluis vervangen lijkt te zijn door een nieuw soort 'materiële toetsingssluis': schending van formele beginselen kan volgens de bestuursrechters op zichzelf niet leiden tot onverbindendheid van een algemeen verbindend voorschrift. Wij begrijpen niet goed wat hiervoor de reden is. Wij vinden zo'n nieuwe sluis onwenselijk, omdat op deze wijze de rechter minder inzichtelijk hoeft te maken hoe hij toetst aan formele beginselen.

$\mathrm{Nu}$ de rechter de rechtmatigheid van wetgeving meer nauwgezet zal (kunnen) beoordelen, en in dat kader mogelijk ook nadere criteria zal moeten ontwikkelen om zijn meer of minder indringende toetsing vorm te geven, is het de vraag hoe de rechtsontwikkeling met betrekking tot de rechtmatigheid(sbeoordeling) van wetgeving verder vorm zal krijgen.

Als gevolg van een terughoudende rol van de rechter zijn de regels inzake de kwaliteit (waaronder de rechtmatigheid) van wetgeving vooral binnen de wetgevingspraktijk op het niveau van het Rijk tot ontwikkeling gekomen. Dit wetgevingskwaliteitsbeleid vervult een belangrijke rol bij de voorbereiding van wetgeving, maar krijgt ook kritiek. Het is onvoldoende transparant en te weinig ingebed in de besluitvorming. De uitspraken van de bestuursrechters inzake exceptieve toetsing evenals de recente review van de OECD van het Nederlandse wetgevingsbeleid kan de aanleiding vormen om dit beleid een impuls te geven. Als de rechter immers algemeen verbindende voorschriften indringender toetst aan algemene beginselen van behoorlijk bestuur, is er een belangrijke nieuwe externe impuls om het zorgvuldigheids- en evenredigheidsbeginsel zo goed mogelijk in het besluitvormingsproces te incorporeren en in de motivering van algemeen verbindende voorschriften terug te laten komen. Mogelijk kan dit wetgevingsbeleid zich zelfs zo goed ontwikkelen dat de Nederlandse rechter op grond hiervan een soort process review van algemeen verbindende voorschriften zal kunnen uitvoeren.

Wij verwachten echter voorlopig niet dat de rechter het wetgevingskwaliteitsbeleid als richtsnoer zal hanteren voor een verdere operationalisering van zijn toetsing. Het wetgevingsbeleid speelt vooral binnen het semiautonome veld van wetgevingsjuristen en -adviseurs en is te eenzijdig gericht op de wetgevingsprocedures binnen de departementen. Het beleid krijgt tot op heden in de rechtspraak nauwelijks aandacht. Waarschijnlijker is daarom dat de bestuursrechter zijn oog 
zal richten op de jurisprudentie van de rechters in Luxemburg of Straatsburg, die hem mede door de bestuursrechtelijke literatuur wordt aangereikt.

Wij willen de wetgever in formele zin echter aanbevelen om nu zelf het heft in handen te nemen. Het ontwikkelen van algemene normen voor bestuurswetgeving kan niet aan de rechter alleen worden overgelaten. Om meer handen en voeten te geven aan de proportionaliteitseis en de procedurele normen van zorgvuldigheid en motivering heeft de rechter een steun in de rug van de wetgever nodig. De eisen die aan wetgeving worden gesteld, fungeren niet alleen als waarborg. $\mathrm{Zij}$ dienen evengoed de effectiviteit van wetgeving als instrument van overheidsbeleid. Deze eisen zouden daarom niet enkel vanuit de positie van de rechter in het staatsbestel of het belang van effectieve rechtsbescherming mogen worden doorontwikkeld.

\section{Epiloog: contouren van een wettelijk kader inzake bestuurswetgeving}

De vraag is hoe een dergelijk wettelijk kader voor bestuurswetgeving eruit zou moeten zien. Tot op heden zijn als gevolg van artikel 3:1, eerste lid, Awb de gecodificeerde algemene beginselen van behoorlijk bestuur slechts in beperkte mate van toepassing op algemeen verbindende voorschriften. Afdeling $3.2 \mathrm{Awb}$ is bijvoorbeeld, op basis van artikel 3:1, eerste lid, onderdeel a, Awb, slechts van toepassing voor zover de aard van de besluiten zich daartegen niet verzet. Gelet op het feit echter dat de strekking van artikel 3:1, eerste lid, onderdeel a, Awb verband houdt met de stand van de jurisprudentie met betrekking tot de toepassing van (ongeschreven) algemene beginselen van behoorlijk bestuur, is het mogelijk dat de beperking van onderdeel a als gevolg van de 1 juli-uitspraken niet meer bestaat. Daarmee zou de harde kern van de wetgevingskwaliteitseisen - te weten het formele zorgvuldigheidsbeginsel, het verbod van détournement de pouvoir, het specialiteitsbeginsel en het evenredigheidsbeginsel - voor bestuurswetgeving als gevolg van de recente uitspraken alsnog (volledig) in de Awb zijn gecodificeerd.

Naar onze mening zou de wetgever dit moeten expliciteren. Deze eisen met betrekking tot de inhoud en de wijze van totstandkoming van wetgeving verdienen wat ons betreft echter aanvulling. Dit zou mogelijk kunnen leiden tot een bijzondere titel in de Awb over bestuurswetgeving, zoals ook voor beschikkingen een bijzonder hoofdstuk bestaat. ${ }^{53}$ Men zou echter ook kunnen denken aan de totstandkoming van een Algemene wet inzake bestuurswetgeving, waarin de belangrijkste materiële en formele eisen aan bestuurswetgeving zijn gecodificeerd. Welke voorkeur men heeft, hangt waarschijnlijk af van de vraag of men de vaststelling van bestuurswetgeving vooral ziet als een reguliere bestuursbevoegdheid, dan wel primair als een wetgevende bevoegdheid die is afgeleid van de bevoegdheden van de wetgever in formele zin. Dat is ons om het even.

Wat zou er dan naast de bepalingen van afdeling 3.2 Awb met betrekking tot bestuurswetgeving moeten worden geregeld? Voor het antwoord op die vraag kan 
bijvoorbeeld inspiratie worden opgedaan in Boek II van de ReNEUAL Model Rules on EU Administrative Procedure met betrekking tot Administrative Rulemaking. ${ }^{54}$ De door ons voorgestelde bepalingen over bestuurswetgeving hebben enerzijds tot doel constitutionele waarden van participatie en transparantie te waarborgen en anderzijds de inachtneming van beginselen van behoorlijk bestuur, in het bijzonder het zorgvuldigheids- en motiveringsvereiste, te verzekeren. Het doel van deze regels is om de kwaliteit en de legitimiteit van bestuurswetgeving te versterken. Zoals in de toelichting op de Model Rules wordt gezegd: 'Greater transparency of input into the procedure as well as the possibility for public debate and deliberation on alternatives will ensure more fully that all the relevant facts and legally protected interests are taken into account, which will contribute to the overall quality of rulemaking. ${ }^{55}$

\section{Geschiktheid, noodzakelijkheid en evenredigheid stricto sensu}

In het bovenstaande betoog hebben wij drie verschillende wijzen van toetsing aan evenredigheid onderscheiden. De willekeurtoets van het Landbouwvliegers-arrest en Maxis/Praxis, de evenredigheidstoets uit de Alcoholslot-uitspraak en de toetsing van evenredigheid via de trits geschiktheid, noodzaak en evenredigheid stricto sensu. Wij menen dat de laatste vorm van toetsing geen overmatige eisen stelt aan de bestuurswetgever en bovendien de rechter in staat stelt om de toetsing aan algemeen verbindende voorschriften beter vorm te geven. Het verdient aanbeveling dit proportionaliteitsvereiste in de wet op te nemen. Dit vereiste biedt vervolgens de grondstructuur voor de onderzoeks- en motiveringsplicht van het bestuur bij het tot stand brengen van bestuurswetgeving. Daarbij geldt dan dat, rekening houdend met de normenhiërarchie bij de zorgvuldigheids- en motiveringsplicht van het lagere voorschrift, ook verwezen kan worden naar de motivering van een hoger voorschrift dat de basis en het kader vormt van het lagere voorschrift.

\section{Zorgvuldige voorbereiding}

Artikel 3:2 Awb bepaalt dat bij de voorbereiding van een besluit het bestuursorgaan de nodige kennis omtrent de relevante feiten en de af te wegen belangen vergaart. Ten aanzien van bestuurswetgeving zou naar het voorbeeld van artikel II-3 van de Model Rules moeten worden bepaald dat het bestuur op zorgvuldige en onpartijdige wijze de relevante feiten en de af te wegen belangen onderzoekt of laat onderzoeken, en dat dit onderzoek in elk geval omvat een onderzoek naar de gevolgen van de voorgenomen beslissing en naar het bestaan van mogelijke alternatieven. De vraag is wel op welke wijze dat onderzoek dient te worden verricht. Wij denken dat daar op dit moment nog onvoldoende zicht op bestaat. Het IAK kent een aantal verplichte toetsen, maar wat ons betreft is vooralsnog onduidelijk of deze ook als een adequate standaard kunnen worden gezien om feiten en belangen in kaart te brengen. Ook is nog maar de vraag of

54 P. Graig, H. Hofmann, J.P. Schneider \& J. Ziller, ReNEUAL Model Rules on EU Administrative Procedure, Oxford: Oxford University Press 2017. 
deze goed hanteerbaar zijn voor bestuurswetgevers buiten de rijksoverheid. Het lijkt nog te vroeg om eisen omtrent het type onderzoek vast te leggen.

\section{Consultatie en participatie}

Nadat het bestuur een ontwerp heeft opgesteld, legt het dit inclusief een memorie van toelichting ter inzage. Vervolgens wordt eenieder in de gelegenheid gesteld om zienswijzen naar voren te brengen. Het bestuur dient andersom ook de mogelijkheid te hebben om bepaalde belanghebbenden die door de regelgeving in hun belangen zullen worden geraakt, uit eigen beweging te benaderen en hen uit te nodigen om een zienswijze op het ontwerp te geven. De naar voren gebrachte zienswijzen worden openbaar gemaakt om het publieke debat te stimuleren. Het nationale wetgevingsbeleid kent nu reeds een verplichting om in principe alle wetgeving in internetconsultatie te brengen, tenzij het bijvoorbeeld om puur technische wijzigingen of de implementatie van EU-regelgeving gaat. Deze consultatieverplichting zou kunnen worden verbreed naar alle bestuurswetgeving die in Nederland wordt uitgevaardigd. Bij het ter inzage leggen van het ontwerp en de memorie van toelichting wordt ook inzicht gegeven in de onderliggende studies, adviezen, data en andere op de bestuurswetgeving betrekking hebbende stukken. In de motivering van het besluit wordt vervolgens ingegaan op de wijze waarop met de opmerkingen uit de consultatie is omgegaan.

\section{Advisering}

Er is geen vorm van verplichte en algemene wetgevingsadvisering die ziet op alle bestuurswetgeving. Afdeling 3.3 Awb omvat regels over advisering. Die afdeling heeft betrekking op een adviseur die bij of krachtens wettelijk voorschrift is belast met het adviseren inzake door een bestuursorgaan te nemen besluiten, en die niet werkzaam is onder verantwoordelijkheid van dat bestuursorgaan. Ingevolge artikel 3:5, tweede lid, Awb is deze afdeling niet van toepassing op het horen van de Raad van State. De Raad van State adviseert wat betreft bestuurswetgeving alleen over algemene maatregelen van bestuur. Een bredere adviesplicht geldt specifiek voor wetgeving die betrekking heeft op de verwerking van persoonsgegevens. ${ }^{56}$ De OECD acht het cruciaal dat er op de naleving van wetgevingskwaliteitseisen voldoende toezicht wordt gehouden door een bestuurlijk lichaam. Mede daarom zouden wij willen vastleggen dat elk bestuursorgaan bij de uitvoering van zijn regelgevende bevoegdheid op verplichte basis over de naleving van wetgevingseisen, in het bijzonder de rechtmatigheid, moet worden geadviseerd door een daartoe ingesteld orgaan. Voor de centrale overheid zou de Raad van State die (bredere) adviesfunctie kunnen vervullen. Voor decentrale overheden zouden voorschriften inzake de decentrale rekenkamers als uitgangspunt kunnen worden genomen voor de inrichting van een decentrale adviesfunctie. ${ }^{57}$ Op deze alsdan wettelijk voorgeschreven advisering aan decentrale overheden zouden de bepalin- 
gen uit afdeling 3.3 Awb dan van toepassing zijn. De motivering van het algemeen verbindend voorschrift zou moeten ingaan op de wijze waarop de bestuurswetgever met het advies is omgegaan.

\section{Motiveringsbeginsel}

Wat betreft het motiveringsbeginsel lijkt het ons ten eerste van belang dat dit beginsel gecodificeerd wordt voor algemeen verbindende voorschriften. Bij de regeling van het motiveringsbeginsel in hoofdstuk 3 van de Awb werden algemeen verbindende voorschriften buiten het toepassingsbereik gelaten. De motivering van algemeen verbindende voorschriften zou te zeer samenhangen met de elders geregelde bekendmaking daarvan. Wij zien deze samenhang echter niet terug in de regels die over de bekendmaking van wettelijke voorschriften zijn gesteld. Daarom zou het geschreven recht met betrekking tot bestuurswetgeving moeten bepalen dat elk algemeen verbindend voorschrift dient te berusten op (1) een deugdelijke motivering, die (2) wordt vermeld bij de bekendmaking van het besluit. Een deugdelijke motivering vereist, zoals hiervoor aangegeven, dat het bestuur in een memorie van toelichting aangeeft dat en hoe het onderzoek heeft gedaan naar de mogelijke gevolgen van de beslissing en welke alternatieven het in zijn overweging heeft betrokken. Daarbij worden ook de onderliggende onderzoeken, adviezen en data actief openbaar gemaakt. Indien het bestuur afwijkt van een uitgebracht advies, wordt dit met redenen voor de afwijking in de motivering vermeld. Ook wordt in de motivering aangegeven dat en hoe het bestuur de in de consultatie naar voren gebrachte zienswijzen in zijn overwegingen heeft betrokken. Anders dan de bestuursrechter op dit moment, menen wij dat het ontbreken van een deugdelijke motivering op zichzelf de onrechtmatigheid van het voorschrift met zich brengt en dus ook reden kan zijn om een wettelijk voorschrift onverbindend te verklaren.

\section{Primaat van de wetgever}

Hierboven hebben wij betoogd dat de intensiteit van de rechtmatigheidstoetsing door de rechter niet moet worden bepaald door de democratische legitimatie van het bestuur dat het voorschrift heeft uitgevaardigd. De democratische legitimatie van het orgaan dient wel de inhoud en omvang van diens regelgevende bevoegdheid te bepalen. Buiten de grondwettelijke delegatieterminologie en beperkingssystematiek zijn er echter op basis van het positieve recht nauwelijks beperkingen gesteld aan de delegatie van regelgevende bevoegdheid. Dit betekent dat de inhoud van veel algemeen verbindende voorschriften wordt vastgesteld door organen die zelf slechts indirect of in het geheel niet democratisch gelegitimeerd zijn.

Wij menen dat zou moeten worden vastgelegd dat bestuurswetgeving geen verplichtingen omvat waarvan de hoofdelementen niet reeds in een besluit van een rechtstreeks democratisch gelegitimeerd lichaam zijn omschreven. Hoewel deze basisregel van het primaat van de wetgever ${ }^{58}$ geen harde scheidslijn biedt, menen we dat dit een belangrijk uitvloeisel zou moeten zijn van het democratie- 
beginsel. Deze norm zou de bevoegdheid van de bestuurswetgever moeten begrenzen en - voor zover nodig - in de rechtspraak nadere invulling moeten krijgen.

De Aanwijzingen voor de regelgeving schrijven daarnaast voor dat zo veel mogelijk in de wet in formele zin worden opgenomen voorschriften:

a die de grondslag vormen voor een stelsel van vergunningen of een stelsel waarbij anderszins de toelaatbaarheid van handelingen afhankelijk wordt gesteld van toestemming van de overheid;

b die andere overheden in medebewind roepen;

c waarbij bestuursorganen in het leven worden geroepen;

d betreffende rechtsbescherming;

e inzake sancties van strafrechtelijke, bestuursrechtelijke of civielrechtelijke aard;

f waarbij toezichts- of opsporingsbevoegdheden worden toegekend;

$\mathrm{g}$ omtrent rechten en verplichtingen van burgers jegens elkaar;

$\mathrm{h}$ die beogen aan de burger procedurele waarborgen te bieden ten aanzien van het gebruik van bevoegdheden door de overheid. ${ }^{59}$

Als tegenhanger van deze aanwijzing zou kunnen worden vastgelegd dat in ieder geval bovengenoemde elementen geen onderdeel vormen van bestuurswetgeving. Wat betreft organieke wetgeving zou men voor vergunningstelsels en sancties hierop een uitzondering kunnen maken, mits die voorschriften door de democratisch gekozen vertegenwoordiging zijn vastgesteld. 